\title{
Indirect Network Effects in New Product Growth
}

\section{Stefan Stremersch, Gerard J. Tellis, Philip Hans Franses and Jeroen L.G. Binken}

\begin{tabular}{|l|l|}
\hline \multicolumn{2}{|l|}{ ERIM REPORT SERIES RESEARCH IN MANAGEMENT } \\
\hline ERIM Report Series reference number & ERS-2007-019-MKT \\
\hline Publication & March 2007 \\
\hline Number of pages & 51 \\
\hline Persistent paper URL & \\
\hline Email address corresponding author & stremersch@few.eur.nl \\
\hline Address & Erasmus Research Institute of Management (ERIM) \\
& RSM Erasmus University / Erasmus School of Economics \\
& Erasmus Universiteit Rotterdam \\
& P.O.Box 1738 \\
& 3000 DR Rotterdam, The Netherlands \\
& Phone: $\quad+31104081182$ \\
& Fax: $\quad+31104089640$ \\
& Email: info@erim.eur.nl \\
& Internet: $\quad$ www.erim.eur.nl \\
\hline
\end{tabular}

Bibliographic data and classifications of all the ERIM reports are also available on the ERIM website: www.erim.eur.nl 


\section{ERASMUS RESEARCH INSTITUTE OF MANAGEMENT}

\section{REPORT SERIES \\ RESEARCH IN MANAGEMENT}

\begin{tabular}{|c|c|}
\hline \multicolumn{2}{|c|}{ ABSTRACT AND KEYWORDS } \\
\hline Abstract & $\begin{array}{l}\text { Indirect network effects are of prime interest to marketers because they affect the growth and } \\
\text { takeoff of software availability for, and hardware sales of, a new product. While prior work on } \\
\text { indirect network effects in the economics and marketing literature is valuable, these literatures } \\
\text { show two main shortcomings. First, empirical analysis of indirect network effects is rare. Second, } \\
\text { in contrast to the importance the prior literature credits to the chicken-and-egg paradox in these } \\
\text { markets, the temporal pattern - which leads which? - of indirect network effects remains } \\
\text { unstudied. Based on empirical evidence of nine markets, this study shows, among others, that: } \\
\text { (1) indirect network effects, as commonly operationalized by prior literature, are weaker than } \\
\text { expected from prior literature; (2) in most markets we examined, hardware sales leads software } \\
\text { availability, while the reverse almost never happens, contradicting existing beliefs. These } \\
\text { findings are supported by multiple methods, such as takeoff and time series analyses, and fit } \\
\text { with the histories of the markets we studied. The findings have important implications for } \\
\text { academia, public policy and management practice. To academia, it identifies a need for new, } \\
\text { and more relevant, conceptualizations of indirect network effects. To public policy, it questions } \\
\text { the need for intervention in network markets. To management practice, it downplays the } \\
\text { importance of the availability of a large library of software for hardware technology to be } \\
\text { successful. }\end{array}$ \\
\hline Free Keywords & Indirect Network Effects, New Product Growth, Takeoff, Chicken-and-Egg \\
\hline Availability & $\begin{array}{l}\text { The ERIM Report Series is distributed through the following platforms: } \\
\text { Academic Repository at Erasmus University (DEAR), DEAR ERIM Series Portal } \\
\text { Social Science Research Network (SSRN), SSRN ERIM Series Webpage } \\
\text { Research Papers in Economics (REPEC), REPEC ERIM Series Webpage }\end{array}$ \\
\hline Classifications & $\begin{array}{l}\text { The electronic versions of the papers in the ERIM report Series contain bibliographic metadata } \\
\text { by the following classification systems: } \\
\text { Library of Congress Classification, (LCC) LCC Webpage } \\
\text { Journal of Economic Literature, (JEL), JEL Webpage } \\
\text { ACM Computing Classification System CCS Webpage } \\
\text { Inspec Classification scheme (ICS), ICS Webpage }\end{array}$ \\
\hline
\end{tabular}




\title{
Indirect Network Effects in New Product Growth
}

\author{
Stefan Stremersch, Gerard J. Tellis, Philip Hans Franses and \\ Jeroen L.G. Binken
}

Final submission to Journal of Marketing

September 2006

Stefan Stremersch is Professor of Marketing at the School of Economics, Erasmus University Rotterdam, The Netherlands, and Visiting Associate Professor of Marketing at the Goizueta Business School, Emory University, USA. Address: Burg. Oudlaan 50, 3062 PA Rotterdam, The Netherlands; tel: +31.10.408.1289, fax: +31.10.408.9160, E-mail:

stremersch@few.eur.nl. Gerard J. Tellis is Professor of Marketing, the Neely Chair of American Enterprise, and director of the Center of Global Innovation, all at the Marshall School of Business, the University of Southern California. Philip Hans Franses is Professor of Econometrics and Marketing Research at Erasmus University Rotterdam. Jeroen L.G. Binken is a PhD student of Marketing, School of Economics, Erasmus University Rotterdam, The Netherlands. The authors thank Henk Speijer (Marketing Intelligence, Philips Consumer Electronics), Martin Zagorsek (NPD) and Peter Golder (New York University) for their help in gathering the data on which this study is based. They appreciate the valuable comments on prior versions by Peter Golder, Jan-Benedict Steenkamp, Christophe Van den Bulte, seminar participants at University of Cambridge and Catholic University Leuven, and participants of the 2006 Innovation Conference (at University of Utah) and the 2006 Informs Marketing Science Conference. They acknowledge the financial support of the Marketing Science Institute (grant \# 4-1152) and the Goldschmeding Center for Increasing Returns (Nyenrode University). We thank the editor and reviewers for their many helpful suggestions. 


\title{
Indirect Network Effects in New Product Growth
}

\begin{abstract}
Indirect network effects are of prime interest to marketers because they affect the growth and takeoff of software availability for, and hardware sales of, a new product. While prior work on indirect network effects in the economics and marketing literature is valuable, these literatures show two main shortcomings. First, empirical analysis of indirect network effects is rare. Second, in contrast to the importance the prior literature credits to the chicken-and-egg paradox in these markets, the temporal pattern - which leads which? - of indirect network effects remains unstudied. Based on empirical evidence of nine markets, this study shows, among others, that: (1) indirect network effects, as commonly operationalized by prior literature, are weaker than expected from prior literature; (2) in most markets we examined, hardware sales leads software availability, while the reverse almost never happens, contradicting existing beliefs. These findings are supported by multiple methods, such as takeoff and time series analyses, and fit with the histories of the markets we studied. The findings have important implications for academia, public policy and management practice. To academia, it identifies a need for new, and more relevant, conceptualizations of indirect network effects. To public policy, it questions the need for intervention in network markets. To management practice, it downplays the importance of the availability of a large library of software for hardware technology to be successful.
\end{abstract}

Keywords: Indirect Network Effects, New Product Growth, Takeoff, Chicken-and-Egg. 


\section{Introduction}

"A familiar high-tech variation on an age-old conundrum is stalling acceptance of the much-heralded computer storage medium known as DVD-ROM: Which comes first, affordable hardware or a wealth of software? The installed base or the content providers?" David Pescovitz in: The Los Angeles Times, July 21, 1997.

TV sets. CD players. DVD players. Economists regularly claim that such markets exhibit indirect network effects ${ }^{1}$. The expected utility of the primary product - and thereby its sales increases as more complements become available, and this availability of complements ${ }^{2}$, in turn, depends on the installed base of the primary product (Caillaud and Jullien 2003; Church and Gandal 1993 and 1996; Cottrell and Koput 1998; Hill 1997; Katz and Shapiro 1994). Prior research has typically referred to the primary product, such as a TV set, a CD player and a DVD player, as hardware and to the product that complements the primary product, such as programming (TV), Compact Discs (CD player), and DVD movies (DVD player), as software (Church and Gandal 1992b; Ducey and Fratrik 1989; Gandal, Kende and Rob 2000; Gupta, Jain and Sawhney 1999). Indirect network effects give rise to the 'chicken-and-egg' paradox: consumers wait to adopt the hardware until enough software is available and software manufacturers delay releasing software until enough consumers have adopted the hardware (Caillaud and Jullien 2003; Gandal 2002; Gupta, Jain and Sawhney 1999). A recent example is the High-Definition television (HDTV) market. The expected utility of HDTV sets to consumers (and therefore HDTV set sales) increases the more HD broadcasting becomes available. On the other hand, broadcasters will make more HD broadcasting available, as the number of consumers owning a HDTV set increases. For HDTV to

\footnotetext{
${ }^{1}$ The phenomenon of indirect network effects is different from the possible interdependence between hardware sales and software sales, such as CD Player sales and CD sales (Bayus 1987; Peterson and Mahajan 1978).

${ }^{2}$ The literature is inconsistent in terminology. Scholars have used the term availability (e.g. Dranove and Gandal 2003; LeNagard-Assayag and Manceau 2001), variety (e.g. Church and Gandal 1992a and 1993), or both interchangeably (e.g. Basu, Mazumdar and Raj 2003; Frels, Shervani and Srivastava 2003; Gandal, Kende and Rob 2000; Katz and Shapiro 1985; Nair, Chintagunta and Dubé 2004), in theory development. Most, if not all, of the empirical studies that have used the term variety operationalize this construct through counting the total complements available (e.g. Basu, Mazumdar and Raj 2003; Gandal, Kende and Rob 2000; Nair, Chintagunta and Dubé 2004). In the present study, we consistently use the term availability, as that corroborates with our measures.
} 
succeed, this ‘chicken-and-egg’ paradox must be resolved (Farrell, et al. 1992; Gandal 2002; Pope 1999).

In the last two decades, several economists have researched various aspects of indirect network effects, including (1) coordination between software and hardware industries (Church and Gandal 1992b; Economides and Salop 1992; Farrell, et al. 1992); (2) standard setting (Church and Gandal 1992a; Clements 2004; Economides 1989; Katz and Shapiro 1985, 1986a, 1992 and 1994); and (3) buyers' technology adoption decisions (Gandal, Kende and Rob 2000; Saloner and Shepard 1995; Shy 1996). While most research in the first two streams relates to choice between rival incompatible systems, the third studies why consumers adopt a given system (Majumdar and Venkataraman 1998). Our study fits within this third research tradition.

Marketing researchers have only recently started to study indirect network effects (Basu, Mazumdar and Raj 2003; Gupta, Jain and Sawhney 1999, LeNagard-Assayag and Manceau 2001; Nair, Chintagunta and Dubé 2004), although the discipline has a relatively longer tradition of studying direct network effects ${ }^{3}$ (e.g. Brynjolfson and Kemerer 1996; Majumdar and Venkataraman 1998; Sun, Xie and Cao 2004; Xie and Sirbu 1995). In addition, some marketing studies focus on network effects per se, independently of whether they are direct or indirect (e.g. Shankar and Bayus 2003; Srinivasan, Lilien and Rangaswamy 2004; Van den Bulte and Stremersch 2004).

Tables 1 and 2 summarize the prior economics and marketing literature. Table 1 contains all empirical papers on indirect network effects and stipulates whether they study demand-side or supply-side indirect network effects or both; whether they define indirect network effects from only the demand-side, only the supply-side, or both; what the focal dependent and independent variables

\footnotetext{
${ }^{3}$ In direct network effects markets, the utility of the product depends directly on the number of others using the same product (Katz and Shapiro 1985).
} 
in their inquiry are; whether they use proxies to measure focal constructs; how many markets they study; whether they have data from the introduction of the new technology; and which markets they study. Table 2 contains a selection of non-empirical papers on indirect network effects. It illustrates what the main focus of this prior work is (whether on indirect network effects specifically or on network effects per se); what the method is (whether mathematical or conceptual); whether they define indirect network effects from only the demand-side, only the supply-side, or both; and which focal dependent and independent variables are included. While this prior literature is valuable and insightful, it also shows some limitations.

First, empirical analysis of indirect network effects is rare and, as evidenced by Table 1, limited to the study of one, exceptionally two, markets. Of the eighteen empirical studies of indirect network effects, seventeen study only one market and only one (Gandal 1995) studies two markets. This situation is probably due to a lack of data on both hardware sales and software availability. Some authors have even claimed that such data is unavailable (Putsis et al. 1997), whereas others (six out of eighteen studies) have used distant proxies, such as the amount of advertising (Gandal, Greenstein and Salant 1999). Still other authors have modeled indirect network effects as if they were direct network effects (Hartman and Teece 1990; Ohashi 2003; Park 2004; Shankar and Bayus 2003). Authors often also do not use data from the introduction of the new technology either (rare exceptions are Dranove and Gandal (2003) and LeNagard-Assayag and Manceau (2001)), leading to potential left-censoring biases. Often, authors also have modeled only one side of indirect network effects, most often so the effect of software availability on hardware sales (demand-side indirect network effects). Moreover, the literature is diverse and inconsistent as to the definition of indirect network effects. Many papers do not even explicitly state a definition of indirect network effects, others provide (inexplicitly) multiple definitions (see the variation on the definition of indirect network effects in Tables 1 and 2). The literature is also inconsistent as to the empirical 
models employed (see the list of dependent and independent variables in Table 1). Therefore we can conclude that the literature lacks a unifying framework to empirically examine indirect network effects.

Second, while the chicken-and-egg paradox is cited a lot, it is unclear how it is resolved. Which comes first, the chicken or the egg? Many business analysts (e.g. Midgette 1997; Tam 2000; Yoder 1990; Ziegler 1994, all in the Wall Street Journal) and academics (Bayus 1987; Bucklin and Sengupta 1993; Clements 2004; Frels, Shervani and Srivastava 2003; Sengupta 1998) have casually observed that a critical mass of software titles is required for hardware sales to take off. Take-off is the point of transition between the introduction stage and the growth stage of a growth curve (Golder and Tellis 1997). Several academics (e.g. Church and Gandal 1992a) have made similar arguments based on theoretical models. However, no one - to our knowledge - has empirically examined whether software availability leads hardware sales or not.

We aim to fill these voids in the present paper. To do so, the present paper examines the temporal pattern of indirect network effects across multiple markets using secondary data, based on prior theories developed in economics and marketing. To do so, the authors have constructed a database, on both hardware sales and software availability, for nine markets, since their inception (the appendix contains a detailed description of the data): Black \& White Television, Compact Disc, CD-ROM, Color Television, DVD, Gameboy, i-Mode, Internet (WWW), and Laserdisc.

The second section of the paper develops the theoretical background of this study. The third section details the data we use. The fourth section presents our empirical analysis. We conclude by summarizing the results, presenting the implications and limitations of our study, and discussing avenues for further research. 


\section{Theoretical Background}

The essence of indirect network effects theory is the understanding that software and hardware form a system (Chou and Shy 1996; Economides 1989; Katz and Shapiro 1994). As they form a system, the supply of software and the demand for hardware may affect each other, according to a specific temporal pattern. Both may also be affected by other variables. For instance, the supply of software may be affected by the supply of software in previous periods and hardware sales may be affected by its price and past hardware sales. We next theorize on all these effects.

\section{Indirect Network Effects}

The theory of indirect network effects argues that the supply of software and the demand for hardware affect each other. The amount of software that is available for a certain technology has a positive influence on the utility of the entire hardware-software system to the consumer (Church and Gandal 1992a; Katz and Shapiro 1985), which draws ever more new adopters to adopt the new hardware (Rogers 1995) and thereby increases hardware sales and the installed base of hardware. In turn, the hardware installed base positively affects software companies’ decisions to make software titles available (Church and Gandal 1993; Gandal 2002). The more consumers that have adopted the hardware product, the larger the market potential for software products for that particular hardware product and therefore the larger the impetus for software companies to provide software titles for the hardware.

Our in-depth review of the literature of indirect network effects (see Tables 1 and 2) suggests at least three forms of indirect network effects, dependent upon the conditions authors have imposed to define them. We call these forms: demand-side indirect network effects, supplyside indirect network effects and demand-and supply-side indirect network effects. Demand-side indirect network effects mean that software availability significantly and positively affects hardware utility of an individual consumer and therefore, at the aggregate level, also hardware sales. Supply- 
side indirect network effects imply that hardware installed base significantly and positively affects the software provision by software manufacturers and therefore, at the aggregate level, software availability. Demand-and supply-side indirect network effects imply that both characteristics exist.

\section{Temporal Pattern in Indirect Network Effects}

The temporal pattern in indirect network effects is important as it can indicate how the chicken-and-egg paradox is resolved. Prior literature has not covered this issue in detail. At the same time, academic scholars and business analysts have expressed very different opinions on this temporal pattern.

A first opinion expressed is that, given extensive coordination between hardware and software manufacturers, growth of software availability coincides with growth in hardware sales (e.g. Katz and Shapiro 1994). Government intervention may coordinate the actions of market participants - both software and hardware - to achieve that. The guidelines of the FCC towards new broadcasting and radio technologies are an example. Hardware manufacturers may also give subsidies, kick-backs, and side payments to software manufacturers to fine-tune software availability to the hardware sales evolution. In the extreme, hardware manufacturers may even vertically integrate into the software industry. An example is RCA's ownership of NBC (when Color Television was introduced).

Others have argued that growth in software availability may precede growth of hardware sales (Bayus 1987; Bucklin and Sengupta 1993; Clements 2004; Frels, Shervani and Srivastava 2003; Sengupta 1998). Church and Gandal (1992a) and business analysts (Midgette 1997; Tam 2000; Yoder 1990; Ziegler 1994) claimed that software availability needs to achieve a critical mass in order for hardware to become a viable alternative, and hardware sales can take off. The reason is that consumers need a sign of sufficient software availability, before they start to adopt the hardware a mass. Also, software companies may invest in software provision before any marked 
hardware sales occur. For instance, Microsoft invested in the CD-ROM long before any significant sales of CD-ROM hardware occurred. Because the CD-ROM was the first mass market high capacity medium that might prove useful in copyright protection, Microsoft envisioned the dramatic advantages it might have for software delivery and installation.

Still other economists (e.g. Dranove and Gandal 2003) have argued that software companies may balk at making software available for new hardware that has not yet taken off. In the early years of most new technologies, the benefits of the new technology are unclear to the software industry. Moreover, different standards may be fighting for dominance, generating even more uncertainty for the software industry. The future mass acceptance of the hardware, and therefore the future profitability of software for the new technology are highly uncertain. Faced with such uncertainty, software companies are unlikely to commit substantial resources to making software available for the new hardware, especially if it requires a high upfront lump sum investment (Ducey and Fratrik 1989). Software providers may only make such investment after hardware sales have taken off and grow rapidly, thus signaling the viability of the new hardware.

At the same time, a critical mass of consumers that adopt the new hardware may develop before a sizeable library of software is available, for several reasons. First, early adopters may like the snob appeal of owning new hardware (Tellis, Stremersch and Yin 2003). Second, cascade effects may prompt consumers to buy new hardware because of their popularity among "opinion leaders” rather than their intrinsic utility (Golder and Tellis 2004). Third, early adopters may create their own content (e.g. i-Mode, Internet (WWW), or VCR) after buying the hardware ${ }^{4}$. Fourth, a killer application (a single software application of very high quality and popularity) may be

\footnotetext{
${ }^{4}$ We thank a reviewer for this insight.
} 
available, by which a sizeable consumer segment "must own" the hardware, regardless of the sheer number of applications available (Frels, Shervani and Srivastava 2003).

\section{Other Effects}

When one empirically examines indirect network effects, other considerations come into play as well, both at the hardware and the software side. At the hardware side, also price of the hardware $^{5}$ and prior hardware sales need to be accounted for. Hardware price will affect the affordability of the new technology, which may affect the adoption of the hardware by consumers, and thereby future sales (Golder and Tellis 1998). Prior hardware sales may affect future hardware sales for several reasons. The most salient reason is probably social contagion, in that past hardware adoptions will influence future hardware adoptions, either through learning under uncertainty or status considerations (Van den Bulte and Stremersch 2004). But there can be several other reasons as well, such as market inertia.

At the software side, two variables may affect software availability. First, past software availability may have an influence on future software availability, though the direction of the influence may be, a priori, unclear (Chou and Shy 1996; Church and Gandal 1992a). It may be positive, because higher past software availability likely increases the utility of the new hardware, thereby increasing the future software sales software providers may expect, consequently encouraging them to make more software available (the "network" effect). It may also be negative, because higher past software availability yields more intense competition among software providers, thereby decreasing the margins software providers can make on their software,

\footnotetext{
${ }^{5}$ One could argue that also software price affects consumers' utility and thereby hardware sales. While this is valid, software prices are in most cases small (or even equal to zero, such as in broadcasting or Internet content), as compared to hardware prices. It is also in most cases, more difficult to obtain information on average software price as compared to average hardware price. Moreover, variation over time may be less in software price than in hardware price. The production of software is likely characterized by high up-front investments and low reproduction costs. Combined with intense competition, software prices are likely to be low (Shapiro and Varian 1998).
} 
consequently discouraging them from making more software available (the “competition” effect). Second, software costs may affect software availability decisions by software providers. High costs involved in providing software for a new technology may discourage software provision by software companies.

\section{Data}

This section describes the data collection and the characteristics of the sample.

\section{Data Collection}

To collect data for the present study, we conducted extensive archival research. The data collection took a great deal of time and effort, because for each market we needed data on hardware sales (and/or hardware installed base), software availability, and hardware price from the time of introduction. As one can see from Table 1, prior empirical research has most often examined the effect of software availability on hardware sales to test for demand-side indirect network effects and the effect of hardware installed base on software availability to test for supply-side indirect network effects. We sought to obtain exactly these variables, rather than any other proxies, as some prior scholars have done (again see Table 1).

We used the following procedure to obtain our data. First, we examined the published literature on consumer electronics (e.g. Ducey and Fratrik 1989; Golder and Tellis 1997). Second, we examined statistical yearbooks (e.g. the Broadcasting and Cable Yearbook, the TV Factbook, the Broadcasting Yearbook, the International TV and Video Almanac, and the CD-ROM directory) in the libraries of two large research universities in the U.S. Some of these sources are also available electronically, but only for more recent years. Third, we contacted organizations directly to assess and access their data archives. Our search led us through approximately 30 public institutions and their libraries (e.g., U.N., the U.S. Federal Communications Commission, U.S. Senate Committees, recording and broadcasting associations, consumer electronics manufacturers’ 
associations) and about 20 private companies that are market research companies, media consultants, manufacturers or software providers. For instance, NPD - a leading research company for marketing and sales information - graciously provided us with hardware sales data and software availability data for Gameboy. In addition, we tried to combine different sources to check for consistency in the data series.

\section{Characteristics of the Sample}

For this study, we focused on consumer electronics, because economic and marketing researchers claim that this class of products shows substantial indirect network effects (Church and Gandal 1993; Ducey and Fratrik 1989; Farrell, et al. 1992; Gupta, Jain and Sawhney 1999).

While we tried to gather data on all consumer electronics markets post WWII, we were able to gather annual data on nine network markets as follows: Black \& White Television, CD, CDROM, Color Television, DVD, Gameboy, i-Mode, Internet (WWW), and Laserdisc. The markets we have data on vary widely from music to video entertainment and ICT to broadcasting. These markets also have the nice feature of being quite diverse in market structure, e.g. in number of manufacturers (from one (Nintendo) for Gameboy to many for television sets and Internet (WWW)), government involvement (from relatively high in television broadcasting to low in Compact Disc or DVD), etc.

All data are from the U.S., except three, namely Compact Disc, Laserdisc, and i-Mode. CD and Laserdisc title availability data were unavailable for the U.S. from their introduction (even after many consultations with the industry and leading publishers), but they were available for Compact Disc in the U.K. (which is clearly a lead market in music) and for Laserdisc in Japan (which is 
clearly a lead market in the most popular Laserdisc applications, such as Karaoke). ${ }^{6}$ I-Mode data were not available for the U.S., while it was for the lead market for i-Mode, Japan.

The precise measures for all our variables and their sources are provided in the Appendix. For some markets, we derived hardware installed base from hardware sales by taking the cumulative sales, as data on hardware installed base was unavailable. Such derivation assumes there are no replacement sales - which is likely in many of our markets as we study the early diffusion process - and is in line with prior literature (Clements and Ohashi 2005; Dranove and Gandal 2003; Gandal, Kende and Rob 2000; Hartman and Teece 1990; Nair, Chintagunta and Dubé 2004; Shankar and Bayus 2003).

Our measures for software availability are consistent with measures other scholars have used in the past. For example, Nair, Chintagunta and Dubé (2004) use the number of software titles available for different PDA platforms. Basu, Mazumdar and Raj (2003), LeNagard-Assayag and Manceau (2001) and Gandal, Kende and Rob (2000) use the number of available Compact Disc titles.

Our measures for hardware prices are the average prices across brands, as is again similar to prior literature (LeNagard-Assayag and Manceau 2001; Shankar and Bayus 2003). For three markets, our measure for price shows specific limitations. In the Compact Disc market, we were unable to obtain hardware prices from the U.K. As we assume the U.K. market has undergone a similar CD player price pattern as the U.S. - e.g. because CD player brands are global players with global manufacturing capacity that determines their prices - we have included the U.S. CD player price as a proxy. In the i-Mode market, we included the average price of i-Mode handsets, which

\footnotetext{
${ }^{6}$ Note that for the CD market, the main problem with data from the U.S. is that the number of released CD’s by independent labels is unavailable, which is about $1 / 3$ to $1 / 4$ of the CD market.
} 
does not include access fees, for which we could not obtain data. In the Internet (WWW) market, we included the average price of a (fax-) modem, as that is the hardware component, and made abstraction of the average price of Internet access.

We display all our data graphically in the results section below (Figure 1), where series have been normalized by dividing the values by the maximum value in the series. This normalization enables better comparison and graphical conclusions, while also retaining confidentiality required to obtain some of the data.

\section{Empirical Analysis}

One can conceive of two ways in which one can empirically analyze the theoretical framework conceived above. First, one can focus on the concept of takeoff and contrast takeoff of hardware sales with takeoff of software availability. Second, one can conceptualize a time series model, based upon the notion of Granger causality. We apply both techniques and discuss each in turn. We end with relating our findings to the historical industry development, lending further credence to the pattern we found.

\section{Takeoff Analysis}

This section explores takeoff in indirect network effects markets. It first derives the concept of takeoff and develops its usefulness in empirically examining the theory derived above. Then it presents the measurement of takeoff, after which it turns to our findings.

\section{Conceptual}

Initially, sales of a new product are generally flat. After some time, a critical mass ${ }^{7}$ of adopters may develop, causing sales to show a distinct takeoff (Golder and Tellis 1997; Rohlfs

\footnotetext{
${ }^{7}$ Threshold and critical mass are terms that are used interchangeably in the sociology and economics literatures (Witt 1997, Macy 1991). For clarity, we consistently use the term critical mass.
} 
2001; Shapiro and Varian 1998). The concept of critical mass was born in physics, where it refers to the point of no return, after which nuclear fusion becomes self-sustaining, and it has subsequently been adopted in sociology, where it refers to the minimum level of activity needed to make an activity self-sustaining (Schelling 1978). Thus, new product takeoff is followed by rapid self-sustaining growth, in which additional consumers adopt the new technology, until the market is saturated and sales show a decline (Golder and Tellis 2004). Hardware sales takeoff has been recognized as an important phenomenon in the marketing literature (Agarwal and Bayus 2002; Golder and Tellis 1997; Tellis, Stremersch, and Yin 2003).

Scholars have argued that the critical mass concept - and thus by consequence, takeoff - is pronounced in markets that are strongly influenced by interdependence of players - as is the case in system markets (Andreozzi 2004; Granovetter 1978; Valente 1995). This fits diffusion literature in marketing that has found that diffusion curves are more pronouncedly S-shaped in markets with competing standards (Van den Bulte 2000; Van den Bulte and Stremersch 2004).

In markets with direct network effects, the utility of the product to consumers depends upon the number of prior adopters. Thus, the critical mass is a certain number of adopters (Katz and Shapiro 1986a). In markets with indirect network effects, there is interdependence, between the utility an adopter derives from the system, and the number of other adopters of the system, because of the availability of complementary products (Katz and Shapiro 1986a; Srinivasan, Lilien and Rangaswamy 2004). Thus, markets with indirect network effects exhibit critical mass not only in consumer adoption of hardware (i.e., the demand side), but also in the amount of available software (i.e., the supply side). Therefore, software availability may show a pattern similar to hardware sales. At first, software companies may balk at providing software, because they doubt the viability of the new technology. After some time, a critical mass of software availability may develop and software availability will show a distinct takeoff. Prior business analysts (e.g. Midgette 1997; Tam 
2000; Yoder 1990; Ziegler 1994) and academics (e.g. Church and Gandal 1992a) have made reference to such phenomenon without examining it in depth.

The takeoff in both hardware sales and software availability are important events in indirect network effects markets in view of the "chicken-and-egg” paradox. The order of takeoff of hardware sales and software availability may provide insight into the temporal pattern of indirect network effects. As we stipulated in our theoretical framework, prior theory is ex ante indeterminate as to what the temporal pattern may be, or in popular terms, what comes first: the chicken or the egg? The empirical study of the temporal order in which takeoff of software availability and hardware sales occur may provide a preliminary answer.

\section{Measurement}

Most prior research has identified takeoff using a heuristic, much like the rules used by Golder and Tellis (1997), Stremersch and Tellis (2004), and Tellis, Stremersch and Yin (2003) (for the only exception, see Agarwal and Bayus (2002)). The spirit of these rules was to call takeoff the first time hardware sales crossed a boundary growth percentage, taking into account the base sales (past sales, as in Golder and Tellis (1997) or penetration, as in Stremersch and Tellis (2004) and Tellis, Stremersch and Yin (2003)). The reason is that growth of $400 \%$ is not that significant when it entails unit sales growth from 100 to 500 units, while it is when it entails unit sales growth from 50,000 to 250,000 .

There are two issues we face in applying these rules to our data that encompass hardware sales as well as software availability. First, there is no natural base against which to benchmark growth of software availability. For instance, 10,000 i-Mode sites may actually be very high, while 10,000 Internet hosts may be extremely low. Second, we have no prior guidance whether the 
growth percentages set forth by these prior studies actually make sense for software availability, as they were developed as heuristics for consumer durable sales.

We define takeoff of hardware sales as the year in which the ratio of change in the growth of sales relative to base sales reaches its maximum before the inflection point in hardware sales. To clarify, change in sales growth is akin to acceleration in sales and is equal to the second difference in sales. Thus, takeoff is the year in which the ratio of the second difference in hardware sales to hardware sales itself is at its maximum. Note that this rule is similar in spirit to the rule provided in the appendix of Golder and Tellis (1997). We define takeoff in software availability, analogously, as the year in which the ratio of change in the growth of software availability relative to base software availability reaches its maximum before the inflection point in software availability.

Earlier studies on takeoff contain four of our nine series on hardware sales. Our identification of the year of takeoff is identical or very similar to that of prior studies in three cases out of four (for CD player sales identical to Tellis, Stremersch and Yin (2003); for CD-ROM sales identical to Golder and Tellis (1997) and for Black \& White Television Set sales 1 year earlier than Golder and Tellis (1997)). These results provide face validity to our method. For Color Television Set sales, our identification of takeoff is 6 years earlier than that of Golder and Tellis (1997). These earlier studies also found that takeoff identified through their heuristic coincided with that from visual inspection in more than $90 \%$ of the cases. In our case, the heuristic rule for takeoff matches with visual inspection in all cases (see Figure 1).

\section{Findings}

Table 3 provides an overview of the takeoff in all markets, while Figure 1 displays them graphically. Comparing columns 4 and 7 of Table 3 and the arrows in Figure 1, shows that for five out of nine markets (Black \& White TV, Compact Disc, i-Mode, Internet (WWW), and Laserdisc), 
hardware sales take off before software availability does. For three out of nine markets (Color TV, DVD, and Gameboy), hardware sales take off at the same time as software availability does. For one market out of nine (CD-ROM), hardware sales take off after software availability has taken off. Table 3 also shows in columns 5 and 8 the amount of available software when hardware sales took off and the level of hardware sales when software availability took off.

We can conclude that, for the nine markets we examined, hardware sales takeoff leads or coincides with software availability takeoff (except in the case of CD-ROM). Moreover, Table 3 shows that hardware sales can take off at very low levels of software availability. For instance, we find that sales of television sets took off with only 7 stations on air. This level is very low compared to over a 1,000 TV stations today. It is also low compared to the 2,000+ radio stations in 1947 (the year of takeoff for Black \& White TV sets). Color TV took off with even remarkably less software - again admittedly judgmental - namely 560 hours a year broadcast in color for the entire United States.

However, the analysis of takeoffs provides only a limited picture on indirect network effects in these markets for several reasons. First, even though we find a clear temporal pattern between takeoffs, it does not prove that indirect network effects actually exist in these markets. Second, one has to be cautious regarding the temporal pattern we find. As our and prior research shows (e.g. Tellis, Stremersch and Yin 2003), uncertainty of several years may surround identification of takeoff. Thus, a difference of one year between the takeoff in hardware sales and the takeoff in software availability is statistically not very meaningful. Third, while drops in hardware price seem to coincide with takeoff in hardware sales (similar to Golder and Tellis 1997), our takeoff analysis is a pure bivariate exercise into the temporal pattern of takeoffs. Given all these limitations, our takeoff analysis should be interpreted with caution. To address these limitations, we next develop a more sophisticated econometric time series model to examine indirect network effects. This time 
series analysis provides other benefits. It allows us to examine the temporal pattern of indirect network effects, while taking the entire history of a market into account, rather than merely one point that is takeoff. Also, it allows us to include other variables that may affect hardware sales, such as past hardware sales and hardware price.

\section{Time Series Analysis}

This section develops a time series analysis to examine indirect network effects and its temporal pattern. It first conceptualizes the modeling framework, after which it turns to the model specification. It then presents the findings from estimating the model and discusses some further analyses we conducted.

\section{Conceptual}

If one wishes to empirically examine the temporal pattern in indirect network effects with aggregate-level secondary data, several considerations should guide the model specification.

First, as we test the model on actual, aggregate-level market data, we need to make some further simplifications to the theory. We do not have data on consumer utility, because such data can only be obtained through experiments, surveys or panels. We also do not have data on the profits software companies expect. Such data would be hard to gather using any empirical methodology. Regarding price, one often has data on only the hardware price and not on the software price. Software price is often complex and thus it is difficult to obtain reliable software price information. Yet, it is often of minor importance and its omission may not seriously compromise conclusions of the model. We also do not have information on software costs, because it is proprietary to software firms. Thus, the empirical model one would wish to specify to empirically examine indirect network effects on secondary data reduces to the model in Figure 2. This model assumes - rather than tests - that the influence of software availability and hardware price on hardware sales occurs through consumers' utility considerations, while it also assumes - 
rather than tests - that the influence of past hardware installed base and past software availability on future software availability occurs through software providers' profit considerations. In addition, it makes abstraction of both software costs and software prices.

Second, given our interest in the temporal pattern of indirect network effects, we wish to refer to the notion of Granger causality (Granger 1969). A process $x_{t}$ is said to Granger cause a process $y_{t}$ if future values of $y_{t}$ can be better predicted using both the past values of process $x_{t}$ and process $y_{t}$, than merely the past values of the process $y_{t}$. Or in mathematical formulation, one says that $x_{t}$ does not Granger cause $y_{t}$ if:

$$
f\left(y_{t} \mid y_{t-1}, x_{t-1}\right)=f\left(y_{t} \mid y_{t-1}\right)
$$

In such case, lagged values of $x_{t}$ do not add any information to the explanation of the movements in $y_{t}$, beyond the past of $y_{t}$ itself. The principle of Granger causality rests on the extent to which a process $x_{t}$ is leading a process $y_{t}$. To include this notion of Granger causality in our model specification, we lag all independent variables in our models.

Third, one may expect (see Figure 1) non-linearities. Therefore, we should use a log transformation to linearize the model in most, if not all, cases.

Fourth, our model is a growth model and thus as time passes, one may expect that the processes we study may approach a certain maximum value (Franses 1998). For this reason, our model also needs to capture a non-linear trend, which we can easily obtain by including a linear trend in log-transformed data. Prior network effects models also include a trend (e.g. Basu, Mazumdar and Raj 2003; Gandal 1994; Shy 2001). We next formally specify our model based on these considerations.

\section{Model}

We specify the following model: 


$$
\begin{aligned}
& \log \left(S_{t}^{H}\right)=\alpha+\beta * \log \left(S_{t-1}^{H}\right)+\gamma^{*} \log \left(A_{t-1}^{S}\right)+\rho^{*} \log \left(P_{t-1}^{H}\right)+\delta^{*} t+\varepsilon_{t} \\
& \log \left(A_{t}^{S}\right)=v+\lambda * \log \left(A_{t-1}^{S}\right)+\eta^{*} \log \left(I B_{t-1}^{H}\right)+\tau^{*} t+\zeta_{t}
\end{aligned}
$$

In which: $S_{t}^{H}$ is hardware sales at time $t, A_{t}^{S}$ is software availability at time $t, P_{t}^{H}$ is price of the hardware at time $t, I B_{t}^{H}$ is hardware installed base at time $t, \alpha$ and $v$ are intercepts, while $\delta$ and $\tau$ capture the time trend. This model specification is a flexible time series model, which we estimate for each market separately, using seemingly unrelated regression (SUR).

\section{Findings}

Table 4 shows the results from estimating equations (2) and (3). The fit statistics for all models are satisfactory. The adjusted $\mathrm{R}^{2}$ ranges from 0.75 to 0.99 . The models also seem to behave well, because there is only one effect that seems implausible, namely the negative coefficient for past software availability on future hardware sales, in the Gameboy market. We next discuss the results.

Theoretically, the most interesting result is that we find that past hardware installed base significantly and positively affects - "leads” in Granger terminology - future software availability in 5 of the 9 markets we examined: Black \& White TV, Compact Disc, Gameboy, Internet (WWW), and Laserdisc. Only one of these markets shows the presence of both demand- and supply-side indirect network effects: Compact Disc. None of the markets we study show only demand-side indirect network effects. This result also allows to conclude that - based on the operationalization of indirect network effects commonly used in the literature and applied in our model through the quantity of available software - demand-and supply-side indirect network effects are less pervasive in the markets we examined than commonly assumed. We graphically represent our results in Figure 3. 
These results are consistent with our earlier findings on takeoff. Of the five markets in which we found supply-side indirect network effects - in Granger's terminology, in which hardware installed base “leads” software availability - four (Black \& White TV, Compact Disc, Internet (WWW), and Laserdisc) show an earlier takeoff of hardware sales than of software availability. On the other hand, in markets where the time series analysis did not show evidence of indirect network effects, the pattern is diverse: the takeoff of hardware sales of CD-ROM lagged the takeoff of CD-ROM software availability; the takeoff of hardware sales and the takeoff of software availability coincided in the cases of Color TV and DVD; the takeoff of hardware sales preceded the takeoff in software availability in one case, i-Mode.

We next discuss the effects of the other variables we included. As one would expect, many - Black\&White TV, Compact Disc, Color TV, Gameboy, Internet (WWW) and Laserdisc - of our markets show a positive influence of past hardware sales on future hardware sales, either due to contagion or other effects, such as inertia. Contrary to what one would expect hardware price does not play a major role in hardware sales growth. However, prior research has presented similar findings (Bayus, Kang and Agarwal 2006). The explanation for these results may be that in many of the markets we study, hardware price is generally not prohibitive. The average hardware price for the markets we study, at introduction, was $\$ 570$. Probably, when one considers more expensive devices the impact of price will be more pronounced. Finally, we find that in two markets (CDROM, and DVD) the effect of past software availability on future software availability is positive and significant, consistent with the "network" effect hypothesis. In the other markets, the coefficient is not significant, either because past software availability does not affect future software availability, or because past software availability affects future software availability both positively (the “network” effect) and negatively (the “competition” effect), or because past software availability affects future software availability in a much more complex pattern than we modeled. 


\section{Further Analyses}

We conducted several other analyses to see how changes to the model may affect our conclusions.

First, one could claim that it would be better to work in first differences. However, econometric theory cannot offer clarity whether this approach is appropriate in our case, as conducting unit root tests is not informative given the limited number of data points (Elliott, Rothenberg, and Stock 1996; Franses 1998). The estimates for the lagged terms of the models in equations (2) and (3) (see Table 4) suggest that differencing may be inappropriate. The reason is that these estimates are far from 1 , while differencing would impose these parameters to be equal to 1. Prior authors in the indirect network effects literature typically do not difference either, with the exception of Gandal, Kende and Rob (2000), who use it to check the robustness of their model. Nonetheless, we decided to conduct these analyses and compare the estimates with our own from estimating the model in equations (2) and (3).

Our findings were the following. First, we found weaker (= insignificant or negative) evidence of indirect network effects, for supply-side indirect network effects in the case of Black \& White TV and Internet (WWW), for demand-side indirect network effects in the case of Compact Disc player. We found stronger evidence of indirect network effects, for supply-side indirect network effects in the case of Color TV and for demand-side indirect network effects in the case of CD-ROM. Second, we found many effects to be implausible. We found one additional case (Compact Disc) in which indirect network effects were found to be negative and two cases (CDROM and Internet (WWW)) in which past hardware sales growth has a negative effect on future hardware sales growth. These findings hint that working in first differences is inappropriate.

Second, we conducted many checks common in time series analysis. As Franses (2005) would categorize our model as a descriptive model, we focused our diagnostic tests on residual 
autocorrelation, heteroscedasticity, and omitted variables. These tests revealed relatively few problems, considering the complexity of our model and the small number of observations. Thus, none of these tests revealed a need for revisions to our model specification.

\section{Historical Industry Analysis}

We next describe each market historically, as it relates to our findings.

Compact Disc. We found strong demand- and supply-side indirect network effects in the Compact Disc market. This market has also been empirically examined the most. Our findings are in line with prior findings. LeNagard-Assayag and Manceau (2001) find that software availability has a positive and significant effect on the consumer's utility, and the hardware installed base has a positive and significant effect on software availability. Basu, Mazumdar and Raj (2003) find that software availability has a significant positive effect on hardware prices. Gandal, Kende and Rob (2000) find that software availability has a positive and significant effect on hardware sales and hardware sales have a positive (but not significant) effect on software availability.

Black \& White $T V$. We found - both in the takeoff and the time series analysis - that in this market hardware leads software. The reason for these effects may lie in the massive investments involved in starting a TV station. It required large outside revenue during the initial years of massive losses. Therefore, many of the early stations were owned by television set manufacturers (e.g. GE and RCA). The revenues they used to sponsor these early TV stations were generated by sales of TV sets (Sterling and Kittross 2002). Therefore, the significant and positive effect of hardware installed base on software availability need not come as a surprise. On the other hand, the sales of TV sets was not much affected by the quantity of software available (as evidenced by the results of our time series analysis), but rather by the technological appeal of television. Television was such a revolutionary new product, that families gave their new TV set a dominant location in 
their living room and for the first couple of weeks, all members of the family marveled at the phenomenon (Sterling and Kittross 2002).

Gameboy. We found that in the Gameboy market hardware leads - though the takeoff analysis shows simultaneous takeoffs in hardware sales and software availability, the time series analysis shows that past hardware installed base positively affects future software availability - and positively affects software availability. Independent software providers respond strongly to the adoption of hardware (Nair, Chintagunta and Dubé 2004), as was the case with Gameboy. Therefore, our finding that availability of Gameboy games grew as more consumers had adopted the Gameboy seems logical. However, why did consumers not react to a growing catalog of Gameboy games? The answer: TETRIS! Tetris is considered to have been a killer application for the Gameboy (Allen 2003; Rowe 1999). Tens of millions of copies of Tetris have been sold since it was introduced simultaneously with the introduction of the Gameboy. It was often bundled with the Gameboy hardware itself. Thus, rather than the evolution in the full catalog of titles available for Gameboy, the availability of one game, Tetris, fueled Gameboy growth.

Internet $(W W W)$. We found - both in the takeoff and the time series analysis - that in the Internet (WWW) market hardware leads software. Again these findings seem logical when one considers the industry evolution. First, Internet users can easily become a software provider by the provision of on-line content (e.g. web pages). Therefore, a growing installed base of users will automatically also lead to a growing base of software providers and thus more Internet hosts (e.g. web servers providing web pages). On the other hand, why do we not find that Internet content stimulates growth in Internet (WWW) adoption? In the first year, the World Wide Web (WWW) already had 80,000 hosts that provided millions of web pages to consumers, more than a single human can possibly read in a lifetime. Also, people used Internet also for other types of 
communication. E-mail predated the birth of the World Wide Web (WWW) and was already a very important application right at the start of the World Wide Web (WWW).

Laserdisc. We found - both in the takeoff and the time series analysis - that in the Laserdisc market hardware leads software. The reason may be very similar to the history of the Black \& White TV. The most important provider of Laserdisc titles was the leading manufacturer of Laserdisc players (Pioneer), because Laserdisc publishing entailed a substantial start-up investment (McClure 1992, 1993a and 1993b; McGowan 1994). Pioneer used hardware sales as a measure for how strong or weak the Laserdisc market was, and accordingly, released a fitting number of titles on Laserdisc. Therefore, we find that past hardware installed base positively affects future software availability. On the other hand, the number of titles available does not affect future hardware sales. This is most likely because most Laserdisc titles released in the 1980s (the time period we study) are not very different from their VHS counterpart, lacking digital sound, widescreen, and extra's (Dick 1990). The provision of such titles did not provide would-be Laserdisc owners with an opportunity to exploit Laserdisc players to their fullest potential. Thus, it gave would-be consumers little reason to purchase a Laserdisc player. Until 1993, Laserdisc titles could only be bought and could not be rented (McClure 1993a), which also made consumers less likely to react to an increase in title availability.

$C D-R O M$. We find no evidence of a significant relationship between software availability and hardware sales in the CD-ROM market. We also find that it is the only market where software availability takes off before hardware sales take off. These findings are in line with the historical development of the CD-ROM market. The early support of Microsoft for the CD-ROM is wellknown and the outcry of Bill Gates "I have no idea what the future will bring for the CD-ROM, but I am willing to invest 1 billion dollars just to find out!” is notorious. Microsoft also hosted the first CD-ROM conferences and developed networks with other content and software providers to write 
for the CD-ROM medium. Microsoft did all this, before a substantial hardware installed base developed. On the other hand, the evolution in hardware sales has been independent from that of software availability, probably due to technological compatibility issues. The first Multimedia PC specifications were only announced at the start of the 1990s - CD-ROM was introduced in 1985 which also set a standard for connecting CD-ROM drives to IBM-compatible PC's. That eased customers' fears about incompatibility. After years of anticipation, the CD-ROM was finally making its way into the home (Alpert 1992).

Color Television. We find no evidence of a significant relationship between software availability and hardware sales in the Color TV market. There may be two major reasons for this result. First, during the first ten years of color broadcasting, NBC was the only vivid supporter of color broadcasting among the major networks. In 1961, CBS and ABC provided their viewers with zero hours of color broadcasting (Ducey and Fratrik 1989). In 1964, NBC would still deliver 95\% of all color broadcasting (Ducey and Fratrik 1989). Because NBC was the only supporter among the main national broadcasters, expansion in color broadcasting (by NBC alone) may not have had a major effect on consumers. Second, networks had to invest a massive 30 to 40 million dollars (1960 dollars!) to purchase the required color equipment, which still excluded additional investments in new graphics, costumes, sets and so on, that were needed as well when going color (Sterling and Kittross 2002). On the other hand, broadcasters did not perceive a major upside of Color TV that would match this massive investment. Broadcasters, such as ABC and CBS did not expect it to expand the installed base of viewers or increase the number of hours viewers watched television. Therefore, there was little incentive to react to growing Color TV set sales, with more color broadcasting, even more as the technology was backward compatible. It was only when the majority of advertising was recorded in color that broadcasters started to invest a mass in color broadcasting equipment (Sterling and Kittross 2002). 
$D V D$. Also for DVD we found no evidence of a significant relationship between software availability and hardware sales. The DVD market has previously been empirically examined by Dranove and Gandal (2003). They use two proxies for software availability in the DVD market: 1) when a particular studio committed to releasing movies on DVD, and 2) the percentage of US boxoffice top 100 movies released on DVD. Only one (percentage of US box-office top 100 films released on DVD) of the two proxies has a positive and significant effect on hardware sales. Thus, the reason why we do not find significant demand-side indirect network effects may be due to the killer application phenomenon cited earlier when we discussed Gameboy history. Consumers may only care about the top titles and on which format they appear, rather than the entire catalog of movies supporting a format. The reason why we do not find supply-side indirect network effects may be due to the immense and early support the DVD technology received from the movie studios (Gandal 2002). Within 18 months after the introduction of the DVD format, all the major movie studios had adopted the DVD format (Dranove and Gandal 2003) and additional hardware sales therefore had no longer any impact on the major movie studios decision to adopt the new DVD technology, making the supply of software largely independent of hardware sales.

$i$-Mode. Also for i-Mode, we do not find any demand- or supply-side indirect network effects. NTT DoCoMo the parent of i-Mode, positioned i-Mode as essentially an extension of preexisting mobile phone services (Ratliff 2002); this may well have contributed to the fact that consumers do not seem to react to increases in the availability of i-Mode services. New hardware characteristics like a built-in camera, and i-Mode’s “always on” feature, may have been the main divers behind hardware sales, rather than the total number of i-Mode sites. i-Mode uses C-HTML (Compact Hyper-Text Markup Language), a form of HTML with a reduced instruction set, which eases the transition for content providers from their already existing HTML web sites to i-Modeready content (Ratliff 2002). This low barrier to entry makes is very easy and relatively profitable 
for content providers to render their services on i-Mode handsets. With the required up-front investment to provide i-Mode services being so small, service providers require only a small number of i-Mode users to turn a profit. This fact may make their decision to provide i-Mode services largely independent of hardware adoption by consumers.

\section{Discussion}

This section summarizes our findings and discusses their implications and limitations.

\section{Summary of Findings}

This study has two main findings. First, we find that indirect network effects as commonly operationalized are less pervasive in the examined markets than expected on the basis of prior literature. This finding contrasts sharply with the "current wisdom”, that the amount of available software is of critical importance to hardware sales growth (e.g. Church and Gandal 1992a; Gupta, Jain and Sawhney 1999; Katz and Shapiro 1986a and 1994).

Second, in most of the markets we examined, hardware sales lead software availability, while the reverse almost never happens. These findings illuminate the temporal pattern of indirect network effects, underlying the chicken-and-egg paradox, which was never empirically examined before. They contradict the widely held view that software availability should lead hardware sales (Bayus 1987; Bucklin and Sengupta 1993; Clements 2004; Frels, Shervani and Srivastava 2003; Midgette 1997; Sengupta 1998; Tam 2000; Yoder 1990; Ziegler 1994).

While there may be many reasons underlying our results - including sampling issues and method artifacts - the most credible, given the variation in the markets examined and the consistency of our findings across methods (takeoff - time series - historical case detail), is that a considerable segment of consumers makes decisions to buy hardware relatively independently of the quantity of software that is available. Thus a critical mass of hardware adopters may gather 
before a critical mass of software titles is available. One probable reason may be the snob appeal of owning new hardware (Tellis, Stremersch and Yin 2003). Other reasons may be cascade effects that prompt consumers to buy new hardware because of their popularity rather than their intrinsic utility (Golder and Tellis 2004) or the fact that users can create their own content after buying the hardware. It may also be that a killer application is available, by which a sizeable consumer segment must own the hardware, regardless of the sheer number of applications available (Frels, Shervani and Srivastava 2003; Williams 2002).

\section{Implications}

To firms, the most important implication is that hardware manufacturers should not overstate the importance of software quantity. Rather, hardware manufacturers should take their fate into their own hands and produce high quality technology with a few (not necessarily many) exciting applications, rather than aiming for very wide availability of a huge library of software. For instance, our results contradict previous calls for hardware manufacturers to pay a lot (in the form of kickbacks and subsidies) to get software companies to provide a huge library of titles.

To public policy, our study is relevant towards government intervention in indirect network effects markets. Often, governments or public institutions are under pressure to intervene in indirect network effects markets to improve coordination between hardware and software companies. Critics claim that the lack of coordination especially in terms of availability of software can slow down the takeoff of the new technology. This claim is hard to maintain in view of our findings. In contrast, we find that in many markets, hardware sales take off before software availability does and, in some markets, at very limited quantities of available software. We also found in our time series that hardware sales mostly lead software availability, instead of software availability leading hardware installed base. Therefore, an important argument for government intervention fades. On the other hand, if intervention were necessary, it might take the form of subsidizing the cost of new 
hardware. While such subsidies may not be reasonable for entertainment products, they might be appealing for products with social benefits, such as electric or hydrogen powered cars.

To academics, the weak evidence we found - using traditional operationalizations of indirect network effects, based on a very long tradition in economics (Church and Gandal 1992a and 1992b; Gandal, Kende and Rob 2000) - fits into new conceptualizations of indirect network effects that may prove more powerful. A first conceptualization is to examine software quality, rather than quantity. Our case detail already illustrated that in some cases (e.g. Tetris in the case of Gameboy), quantity does not matter, but the presence of killer applications does. There is very little scholarly research that examines the role of killer applications, while the phenomenon is deemed very important, especially in certain industries, such as the video game console market. A second conceptualization may revolve around the notion that network effects may be more restricted in scope than previously assumed (Tucker 2006). As such, the entire catalog of software may not be relevant to consumers, but only a very small selection of it may be (e.g. a genre). A third conceptualization may revolve around the notion of thresholds. Software availability may need to cross a threshold at introduction to make the technology credible. Research that extends indirect network effects in these directions may be very impactful.

\section{Limitations}

This paper examines a complex phenomenon in an area in which data are very scarce. It is easy to point at its limitations, which we hope future research will address.

First, due to data limitations, we could not include other important explanatory variables, such as software price, software costs, software and hardware entry, nor could we address possible threshold effects (also see Bayus 1987). We were also unable to test the underlying theoretical mechanisms - consumers' utility considerations and software providers’ profitability considerations - of our model. 
Second, we study only nine network markets. Although this is a relatively small sample, it compares favorably with prior studies in this area that examined only one or two markets.

Third, we study only surviving technologies. Future research that studies the role of indirect network effects in new technology failure would be interesting.

Fourth, we focused on countries that can generally be considered lead countries in the given technology. It would be interesting to examine if uncertainty from indirect network effects is lower in lag countries than in lead countries. Research that focuses on indirect network effects in an international setting would be most fruitful.

Fifth, the role of consumer expectations is of great importance in indirect network effects markets. However, it is not included in our model due to data limitations. Incorporating consumer expectations in future models may provide new insights. 
Table 1:

\section{Overview of Empirical Literature on Indirect Network Effects}

\begin{tabular}{|c|c|c|c|c|c|c|c|c|c|c|c|c|c|}
\hline & \multirow{2}{*}{$\begin{array}{l}\text { Demand or } \\
\text { Supply-side }\end{array}$} & \multicolumn{4}{|c|}{ Definition of Indirect Network Effects } & \multicolumn{2}{|c|}{ Dependent Variable } & \multicolumn{2}{|c|}{ Independent Variable } & \multirow{2}{*}{$\begin{array}{c}\text { Uses } \\
\text { Proxies }\end{array}$} & \multirow{2}{*}{$\begin{array}{c}\text { Nr. of } \\
\text { Markets }\end{array}$} & \multirow{2}{*}{$\begin{array}{c}\text { Data from } \\
\text { introduction? }\end{array}$} & \multirow[t]{2}{*}{ Markets } \\
\hline & & $\begin{array}{l}\text { Demand- } \\
\text { side }\end{array}$ & $\begin{array}{l}\text { Supply } \\
\text {-side }\end{array}$ & Both & Other & $\begin{array}{l}\text { In } \mathrm{HW}^{*} \\
\text { equation }\end{array}$ & $\begin{array}{l}\text { In SW* } \\
\text { equation }\end{array}$ & $\begin{array}{l}\text { In } \mathrm{HW}^{*} \\
\text { equation }\end{array}$ & $\begin{array}{l}\text { In SW* } \\
\text { equation }\end{array}$ & & & & \\
\hline Basu, Mazumdar and Raj (2003) & Demand & $\mathrm{V}$ & & & & $\mathrm{HP}$ & & SA & & No & 1 & No & $\mathrm{CD}$ \\
\hline Clements and Ohashi (2005) & Both & & & $\mathrm{V}$ & & HMS & SA & SA & HIB & No & 1 & Partial & Video Game \\
\hline Cottrell and Koput (1998) & Demand & & & $\mathrm{V}$ & & HP & & HMS, SA & & No & 1 & No & Microcomputer \\
\hline Dranove and Gandal (2003) & Demand & & & $\mathrm{V}$ & & HS & & SA & & Yes & 1 & Yes & DVD Player \\
\hline $\begin{array}{l}\text { Frels, Shervani and Srivastava } \\
\text { (2003) }\end{array}$ & Demand & $\mathrm{V}$ & & & & RA & & SA & & No & 1 & No & Computer \\
\hline Gandal (1995) & Demand & & & $\mathrm{V}$ & & & SP & & $\mathrm{C}$ & No & 2 & No & Spreadsheet and DMS \\
\hline $\begin{array}{l}\text { Gandal, Greenstein and Salant } \\
\text { (1999) }\end{array}$ & Both & & & $\mathrm{V}$ & & HS & SA & SA & HS & Yes & 1 & No & $\mathrm{CP} / \mathrm{M}$ and DOS \\
\hline Gandal, Kende and Rob (2000) & Both & & & $\mathrm{V}$ & & HIB & SA & SA & HIB & No & 1 & No & $\mathrm{CD}$ \\
\hline Gupta, Sachin and Sawhney (1999) & Both & & & $\mathrm{V}$ & & CD & CR & SA & CD & No & 1 & No & Television \\
\hline Hartman and Teece (1990) & Demand & & $\mathrm{V}$ & & & HMS & & $\begin{array}{l}\text { HMS, } \\
\text { HIB }\end{array}$ & & Yes & 1 & No & Minicomputer \\
\hline $\begin{array}{l}\text { LeNagard-Assayag and Manceau } \\
\text { (2001) }\end{array}$ & Both & & & $\mathrm{V}$ & & HIB & SA & SA & HIB & No & 1 & Yes & CD (France) \\
\hline Nair, Chintagunta, Dube (2004) & Both & & & $\mathrm{V}$ & & HS & SA & SA & HIB & No & 1 & No & PDA \\
\hline Ohashi (2003) & Demand & & & $\mathrm{V}$ & & HMS & & HIB & & Yes & 1 & No & VCR \\
\hline Park (2004) & Demand & & & V & & HMS & & $\begin{array}{l}\text { HMS, } \\
\text { HIB }\end{array}$ & & Yes & 1 & No & VCR \\
\hline Rysman (2004) & Both & & & $\mathrm{V}$ & & $\mathrm{CD}$ & $\mathrm{SP}$ & SA & $\mathrm{CD}$ & No & 1 & No & Yellow Pages \\
\hline Saloner and Shepherd (1995) & Supply & & & & $\mathrm{V}$ & & SD & & HS & Yes & 1 & No & ATM \\
\hline Shankar and Bayus (2003) & Demand & & & $\mathrm{V}$ & & HS & & HIB & & No & 1 & No & Video Game Console \\
\hline Shurmer (1993) & Demand & & $\mathrm{V}$ & & & $\mathrm{CD}$ & & SA & & No & 1 & No & PC Sofware (UK) \\
\hline This Study & Both & & & $\mathbf{V}$ & & HS & SA & SA & HIB & No & 9 & Yes & $\begin{array}{l}\text { B\&WTV, CD, CD- } \\
\text { ROM, CTV, DVD, GB, } \\
\text { i-Mode, Internet, LD }\end{array}$ \\
\hline
\end{tabular}

* C: Compatibility, CD: Consumer Demand, CR: Complementor Response, HIB: Hardware Installed base, HMS: Hardware Market Share, HP: Hardware Price, HS: Hardware Sales, RA: Resource

Allocation, SA: Software Availability, SD: Software Deployment SP: Software Price. 
Table 2:

Overview of Non-Empirical Literature on Indirect Network Effects

\begin{tabular}{|c|c|c|c|c|c|c|c|c|c|c|}
\hline & \multirow{2}{*}{$\begin{array}{c}\text { Main } \\
\text { Focus* }\end{array}$} & \multirow[t]{2}{*}{ Method** } & \multicolumn{4}{|c|}{ Definition of Indirect Network Effects } & \multicolumn{2}{|c|}{ Dependent Variable Model } & \multicolumn{2}{|c|}{ Independent Variable Model } \\
\hline & & & $\begin{array}{l}\text { Demand- } \\
\text { side }\end{array}$ & Supply-side & Both & Other & Hardware*** & Software*** & Hardware*** & Software*** \\
\hline Bental and Spiegel (1995) & $\mathrm{NE}$ & $\mathrm{C}$ & & $\mathrm{V}$ & & & & & & \\
\hline Bonardi and Durand (2003) & $\mathrm{NE}$ & $\mathrm{C}$ & & & $\mathrm{V}$ & & & & & \\
\hline Caillaud and Jullien (2003) & INE & M & & & $\mathrm{V}$ & & $\mathrm{CU}$ & $\mathrm{CP}$ & SA & HMS \\
\hline Choi (1994) & NE & $\mathrm{C}$ & $\mathrm{V}$ & & & & & & & \\
\hline Chou and Shy (1990) & INE & M & $\mathrm{V}$ & & & & $\mathrm{CU}$ & $\mathrm{CP}$ & SA & SA \\
\hline Chou and Shy (1993) & INE & M & $\mathrm{V}$ & & & & $\mathrm{CU}$ & SA & SA & HMS \\
\hline Chou and Shy (1996) & INE & M & $\mathrm{v}$ & & & & $\mathrm{CU}$ & SA & SA & HIB \\
\hline Church and Gandal (1992a) & INE & $\mathrm{M}$ & $\mathrm{v}$ & & & & $\mathrm{CU}$ & $\mathrm{CP}$ & SA & SA \\
\hline Church and Gandal (1992b) & INE & $\mathrm{M}$ & $\mathrm{v}$ & & & & $\mathrm{CU}$ & $\mathrm{CP}$ & SA & HMS \\
\hline Church and Gandal (1993) & INE & $\mathrm{M}$ & & & $\mathrm{v}$ & & $\mathrm{CU}$ & SE & SA & HIB \\
\hline Church and Gandal (1996) & INE & M & & & $\mathrm{v}$ & & $\mathrm{CU}$ & $\mathrm{CP}$ & SA & SA \\
\hline Clark and Chatterjee (1999) & $\mathrm{NE}$ & M & & & $\mathrm{V}$ & & $\mathrm{CU}$ & & SA & \\
\hline Clements (2004) & $\mathrm{NE}$ & M & & & $\mathrm{v}$ & & & SE & & HIB \\
\hline $\begin{array}{l}\text { Conner (1995) } \\
\text { Cons }\end{array}$ & NE & $\mathrm{C}$ & $\mathrm{v}$ & & & & & & & \\
\hline Dhebar (1995) & INE & $\mathrm{C}$ & & & $\mathrm{V}$ & & & & & \\
\hline Economides (1996) & INE & $\mathrm{C}$ & & & & $\mathrm{V}$ & & & & \\
\hline Economides and Himmelberg (1995) & $\mathrm{NE}$ & $\mathrm{C}$ & $\mathrm{V}$ & & & & & & & \\
\hline Economides and White (1994) & $\mathrm{NE}$ & $\mathrm{C}$ & & & & $\mathrm{v}$ & & & & \\
\hline Esser and Leruth (1988) & $\mathrm{NE}$ & $\mathrm{C}$ & $\mathrm{v}$ & & & & & & & \\
\hline Farrell and Saloner (1985) & $\mathrm{NE}$ & $\mathrm{C}$ & & $\mathrm{V}$ & & & & & & \\
\hline Farrell and Saloner (1986) & $\mathrm{NE}$ & M & $\mathrm{V}$ & & & & $\mathrm{CU}$ & & HIB & \\
\hline $\begin{array}{l}\text { Gandal (2002) } \\
\text { Gal (1500) }\end{array}$ & NE & $\mathrm{M}$ & & & $\mathrm{v}$ & & $\mathrm{CU}$ & & SA & \\
\hline Garud and Kumaraswamy (1993) & NE & $\mathrm{C}$ & & $\mathrm{v}$ & & & & & & \\
\hline Hahn (2003) & NE & $\mathrm{C}$ & & & & $\mathrm{V}$ & & & & \\
\hline
\end{tabular}


Table 2:

Overview of Non-Empirical Literature on Indirect Network Effects (ctd.)

\begin{tabular}{|c|c|c|c|c|c|c|c|c|c|c|}
\hline & \multirow{2}{*}{$\begin{array}{l}\text { Main } \\
\text { Focus* }\end{array}$} & \multirow[t]{2}{*}{ Method** } & \multicolumn{4}{|c|}{ Definition of Indirect Network Effects } & \multicolumn{2}{|c|}{ Dependent Variable Model } & \multicolumn{2}{|c|}{ Independent Variable Model } \\
\hline & & & Demand-side & Supply-side & Demand- and Supply-side & Other & Hardware*** & Software*** & Hardware*** & Software*** \\
\hline Hill (1997) & $\mathrm{O}$ & $\mathrm{C}$ & & & $\mathrm{V}$ & & $\mathrm{CU}$ & SA & SA & HIB \\
\hline Katz and Shapiro (1985) & NE & C & & $\mathrm{V}$ & & & & & & \\
\hline Katz and Shapiro (1986a) & $\mathrm{NE}$ & M & & $\mathrm{V}$ & & & $\mathrm{CU}$ & & HIB & \\
\hline Katz and Shapiro (1986b) & NE & M & & $\mathrm{V}$ & & & $\mathrm{CU}$ & & HIB & \\
\hline Katz and Shapiro (1992) & NE & $\mathrm{C}$ & & $\mathrm{V}$ & & & & & & \\
\hline Katz and Shapiro (1994) & INE & C & & $\mathrm{V}$ & & & & & & \\
\hline Koski and Kretschmer (2004) & $\mathrm{NE}$ & $\mathrm{C}$ & & & $\mathrm{V}$ & & $\mathrm{CU}$ & SA & SA & HIB \\
\hline Kotabe, Sahay and Aulakh (1996) & $\mathrm{O}$ & C & & & $\mathrm{V}$ & & & & & \\
\hline Kristiansen (1996) & NE & $\mathrm{C}$ & & & $\mathrm{V}$ & & & & & \\
\hline Kristiansen (1998) & $\mathrm{NE}$ & C & $\mathrm{V}$ & & & & & & & \\
\hline Lee and O’Connor (2003) & $\mathrm{NE}$ & $\mathrm{C}$ & & & $\mathrm{V}$ & & $\mathrm{CU}$ & SA & SA & HIB \\
\hline Loch and Huberman (1999) & NE & $\mathrm{C}$ & & $\mathrm{V}$ & & & & & & \\
\hline Matutes and Regibeau (1988) & $\mathrm{O}$ & $\mathrm{C}$ & & $\mathrm{V}$ & & & & & & \\
\hline Matutes and Regibeau (1992) & $\mathrm{O}$ & $\mathrm{C}$ & & $\mathrm{V}$ & & & & & & \\
\hline Postrel (1990) & $\mathrm{NE}$ & $\mathrm{C}$ & $\mathrm{V}$ & & & & & & & \\
\hline Rohlfs (2001) & $\mathrm{NE}$ & $\mathrm{C}$ & & & $\mathrm{V}$ & & & & & \\
\hline Schilling (1999) & $\mathrm{O}$ & $\mathrm{C}$ & & & $\mathrm{V}$ & & HIB & SA & SA & HIB \\
\hline Schilling (2002) & $\mathrm{O}$ & C & & & $\mathrm{V}$ & & & & & \\
\hline Shapiro and Varian (1998) & $\mathrm{NE}$ & $\mathrm{C}$ & & & $\mathrm{V}$ & & & & & \\
\hline Sheremata (2004) & $\mathrm{NE}$ & C & & & $\mathrm{V}$ & & & & & \\
\hline Shy (2001) & $\mathrm{NE}$ & M & & & $\mathrm{V}$ & & & SA & & HIB \\
\hline Srinivasan, Lilien and Rangaswamy (2004) & $\mathrm{NE}$ & $\mathrm{C}$ & & & $\mathrm{V}$ & & & & & \\
\hline Thum (1994) & $\mathrm{NE}$ & C & & $\mathrm{V}$ & & & & & & \\
\hline Valente (1995) & $\mathrm{O}$ & $\mathrm{C}$ & $\mathrm{V}$ & & & & & & & \\
\hline Viswanathan (2005) & NE & C & & $\mathrm{V}$ & & & & & & \\
\hline Wade (1995) & $\mathrm{NE}$ & C & & & $\mathrm{V}$ & & & & & \\
\hline Xie and Sirbu (1995) & $\mathrm{NE}$ & $\mathrm{C}$ & & & $\mathrm{V}$ & & & & & \\
\hline
\end{tabular}

*: main focus can be on network effects in general, denoted by NE, indirect network effects, denoted by INE, or other, denoted by O.

**: method can be conceptual (containing verbal or graphical logic), denoted by C, or mathematical (containing a mathematical formulation), denoted by M.

*** CU: Consumer Utility, CP: Complementor Profit, HIB: Hardware Installed Base, HMS: Hardware Market Share, SA: Software Availability, SE: Software Entry. 
Table 3:

Takeoff Analysis Results

\begin{tabular}{|c|c|c|c|c|c|c|c|}
\hline \multirow[b]{2}{*}{ Market } & \multirow[b]{2}{*}{$\begin{array}{c}\text { Introduction } \\
\text { Year }\end{array}$} & \multicolumn{3}{|c|}{ Hardware Sales } & \multicolumn{3}{|c|}{ Software Availability } \\
\hline & & $\begin{array}{c}\text { Takeoff } \\
\text { Year }\end{array}$ & $\begin{array}{c}\text { Time to } \\
\text { Takeoff } \\
\text { (in years) }\end{array}$ & $\begin{array}{c}\text { Software } \\
\text { Availability } \\
\text { at Hardware } \\
\text { Sales } \\
\text { Takeoff }\end{array}$ & $\begin{array}{c}\text { Takeoff } \\
\text { Year }\end{array}$ & $\begin{array}{c}\text { Time to } \\
\text { Takeoff } \\
\text { (in } \\
\text { years) }\end{array}$ & $\begin{array}{c}\text { Hardware } \\
\text { Sales at } \\
\text { Software } \\
\text { Availability } \\
\text { Takeoff }\end{array}$ \\
\hline $\begin{array}{l}\text { B\&W } \\
\text { Television }\end{array}$ & 1939 & 1947 & 8 & $\begin{array}{l}7 \text { stations } \\
\text { on air }\end{array}$ & 1948 & 9 & $\begin{array}{c}970,000 \text { unit } \\
\text { sales }\end{array}$ \\
\hline $\begin{array}{l}\text { Compact } \\
\text { Disc }\end{array}$ & 1983 & 1985 & 2 & 5,000 titles & 1988 & 5 & $\begin{array}{l}\text { 770,000 unit } \\
\text { sales }\end{array}$ \\
\hline CD-ROM & 1985 & 1990 & 5 & 1,522 titles & 1988 & 3 & $\begin{array}{l}\text { 20,000 unit } \\
\text { sales }\end{array}$ \\
\hline $\begin{array}{l}\text { Color } \\
\text { Television }\end{array}$ & 1954 & 1956 & 2 & $\begin{array}{l}560 \text { hours } \\
\text { in color }\end{array}$ & 1956 & 2 & $\begin{array}{l}\text { 100,000 unit } \\
\text { sales }\end{array}$ \\
\hline DVD & 1997 & 1999 & 2 & 3,084 titles & 1999 & 2 & $\begin{array}{l}\text { 3,095,654 } \\
\text { unit sales }\end{array}$ \\
\hline Gameboy & 1989 & 1991 & 2 & 156 games & 1991 & 2 & $\begin{array}{l}4.4 \text { mln unit } \\
\text { sales }\end{array}$ \\
\hline i-Mode & 1999 & 2000 & 1 & 10,000 sites & 2001 & 2 & $\begin{array}{l}23,039,000 \\
\text { subscribers }\end{array}$ \\
\hline $\begin{array}{l}\text { Internet } \\
\text { (WWW) }\end{array}$ & 1991 & 1994 & 3 & $\begin{array}{l}2,217,000 \\
\text { hosts }\end{array}$ & 1995 & 4 & $\begin{array}{c}25 \text { mln } \\
\text { subscribers }\end{array}$ \\
\hline Laserdisc & 1981 & 1983 & 2 & 649 titles & 1985 & 4 & $\begin{array}{l}\text { 229,012 unit } \\
\text { sales }\end{array}$ \\
\hline
\end{tabular}


Table 4:

Time Series Analysis Results

\begin{tabular}{|c|c|c|c|c|c|c|c|c|c|c|}
\hline & \multicolumn{2}{|c|}{ Black \& White TV } & \multicolumn{2}{|c|}{ Compact Disc } & \multicolumn{2}{|c|}{ CD-ROM } & \multicolumn{2}{|c|}{ Color TV } & \multicolumn{2}{|c|}{ DVD } \\
\hline & $\log \left(S_{t}^{H}\right)$ & $\log \left(A_{t}^{S}\right)$ & $\log \left(S_{t}^{H}\right)$ & $\log \left(A_{t}^{S}\right)$ & $\log \left(S_{t}^{H}\right)$ & $\log \left(A_{t}^{S}\right)$ & $\log \left(S_{t}^{H}\right)$ & $\log \left(A_{t}^{S}\right)$ & $\log \left(S_{t}^{H}\right)$ & $\log \left(A_{t}^{S}\right)$ \\
\hline Intercept & $\begin{array}{c}13.38^{* * *} \\
(4.05)\end{array}$ & $\begin{array}{l}-0.71 \\
(0.62)\end{array}$ & $\begin{array}{l}1.40^{* *} \\
(0.57)\end{array}$ & $\begin{array}{c}6.15^{* * * *} \\
(0.38)\end{array}$ & $\begin{array}{c}3.10 \\
(10.21)\end{array}$ & $\begin{array}{c}1.41 \\
(1.62)\end{array}$ & $\begin{array}{c}-7.92 \\
(13.18)\end{array}$ & $\begin{array}{c}4.41^{* * * *} \\
(1.00)\end{array}$ & $\begin{array}{c}-2.69 \\
(14.89)\end{array}$ & $\begin{array}{c}4.57 * * * \\
(0.42)\end{array}$ \\
\hline Time & $\begin{array}{c}0.00 \\
(0.07)\end{array}$ & $\begin{array}{l}0.17^{*} \\
(0.09)\end{array}$ & $\begin{array}{c}-0.24 * * * \\
(0.02)\end{array}$ & $\begin{array}{c}0.23^{* * * *} \\
(0.02)\end{array}$ & $\begin{array}{c}0.97 \\
(0.58)\end{array}$ & $\begin{array}{l}-0.13 \\
(0.35)\end{array}$ & $\begin{array}{l}0.51^{* *} \\
(0.20)\end{array}$ & $\begin{array}{c}0.19 * * * \\
(0.06)\end{array}$ & $\begin{array}{l}-0.19 \\
(0.31)\end{array}$ & $\begin{array}{c}0.19 * * * \\
(0.04)\end{array}$ \\
\hline $\log \left(S_{t-1}^{H}\right)$ & $\begin{array}{c}0.69 * * * \\
(0.11)\end{array}$ & & $\begin{array}{c}0.51 * * * \\
(0.03)\end{array}$ & & $\begin{array}{l}-0.09 \\
(0.11)\end{array}$ & & $\begin{array}{l}0.54^{*} \\
(0.28)\end{array}$ & & $\begin{array}{c}0.58 \\
(0.44)\end{array}$ & \\
\hline $\log \left(A_{t-1}^{S}\right)$ & $\begin{array}{l}-0.39 \\
(0.32)\end{array}$ & $\begin{array}{c}0.15 \\
(0.24)\end{array}$ & $\begin{array}{c}0.77 * * * \\
(0.05)\end{array}$ & $\begin{array}{c}0.08 \\
(0.07)\end{array}$ & $\begin{array}{c}0.13 \\
(0.65)\end{array}$ & $\begin{array}{c}0.95^{* * *} \\
(0.25)\end{array}$ & $\begin{array}{l}-0.87 \\
(0.60)\end{array}$ & $\begin{array}{l}-0.07 \\
(0.40)\end{array}$ & $\begin{array}{c}0.83 \\
(0.47)\end{array}$ & $\begin{array}{l}0.38^{*} \\
(0.18)\end{array}$ \\
\hline $\log \left(I B_{t-1}^{H}\right)$ & & $\begin{array}{c}0.22 * * * \\
(0.07)\end{array}$ & & $\begin{array}{l}0.09^{*} \\
(0.05)\end{array}$ & & $\begin{array}{c}0.03 \\
(0.25)\end{array}$ & & $\begin{array}{c}0.14 \\
(0.19)\end{array}$ & & $\begin{array}{c}0.01 \\
(0.10)\end{array}$ \\
\hline $\log \left(P_{t-1}^{H}\right)$ & $\begin{array}{l}-1.28 \\
(0.87)\end{array}$ & & $\begin{array}{l}-0.04 \\
(0.08)\end{array}$ & & $\begin{array}{c}0.54 \\
(1.37)\end{array}$ & & $\begin{array}{c}2.69 \\
(2.38)\end{array}$ & & $\begin{array}{c}0.72 \\
(1.88)\end{array}$ & \\
\hline Adj R-squared & 0.96 & 0.95 & 0.99 & 0.99 & 0.91 & 0.96 & 0.91 & 0.92 & 0.99 & 0.99 \\
\hline \# observations & 11 & 11 & 11 & 11 & 8 & 8 & 11 & 11 & 7 & 7 \\
\hline
\end{tabular}


Table 4:

Time Series Analysis Results (ctd.)

\begin{tabular}{|c|c|c|c|c|c|c|c|c|}
\hline & \multicolumn{2}{|c|}{ Gameboy } & \multicolumn{2}{|c|}{ i-Mode } & \multicolumn{2}{|c|}{ Internet (WWW) } & \multicolumn{2}{|c|}{ Laser Disc } \\
\hline & $\log \left(S_{t}^{H}\right)$ & $\log \left(A_{t}^{S}\right)$ & $\log \left(S_{t}^{H}\right)$ & $\log \left(A_{t}^{S}\right)$ & $\log \left(S_{t}^{H}\right)$ & $\log \left(A_{t}^{S}\right)$ & $\log \left(S_{t}^{H}\right)$ & $\log \left(A_{t}^{S}\right)$ \\
\hline Intercept & $\begin{array}{c}7.04^{* * *} \\
(1.88)\end{array}$ & $\begin{array}{c}-10.65^{*} \\
(5.13)\end{array}$ & $\begin{array}{c}51.54 \\
(46.25)\end{array}$ & $\begin{array}{c}1.60^{* * *} \\
(0.22)\end{array}$ & $\begin{array}{c}-60.16 \\
(50.58)\end{array}$ & $\begin{array}{c}-0.43 \\
(1.92)\end{array}$ & $\begin{array}{l}-4.69 \\
(4.90)\end{array}$ & $\begin{array}{c}0.33 \\
(0.69)\end{array}$ \\
\hline Time & $\begin{array}{c}0.13^{* * *} \\
(0.03)\end{array}$ & $\begin{array}{c}0.02 \\
(0.03)\end{array}$ & $\begin{array}{l}-0.30 \\
(1.70)\end{array}$ & $\begin{array}{c}0.01 \\
(0.01)\end{array}$ & $\begin{array}{l}-0.36 \\
(0.48)\end{array}$ & $\begin{array}{c}0.17 \\
(0.11)\end{array}$ & $\begin{array}{c}0.03 \\
(0.05)\end{array}$ & $\begin{array}{c}0.13 * * * * \\
(0.03)\end{array}$ \\
\hline $\log \left(S_{t-1}^{H}\right)$ & $\begin{array}{c}0.66^{* *} \\
(0.26)\end{array}$ & & $\begin{array}{l}-0.25 \\
(2.08)\end{array}$ & & $\begin{array}{l}0.86^{*} \\
(0.48)\end{array}$ & & $\begin{array}{l}0.47^{*} \\
(0.23)\end{array}$ & \\
\hline $\log \left(A_{t-1}^{S}\right)$ & $\begin{array}{c}-0.42^{* *} \\
(0.18)\end{array}$ & $\begin{array}{l}-0.32 \\
(0.24)\end{array}$ & $\begin{array}{c}3.95 \\
(20.99)\end{array}$ & $\begin{array}{c}0.74 \\
(0.69)\end{array}$ & $\begin{array}{c}1.34 \\
(1.25)\end{array}$ & $\begin{array}{l}-0.04 \\
(0.41)\end{array}$ & $\begin{array}{c}0.30 \\
(0.30)\end{array}$ & $\begin{array}{l}-0.28 \\
(0.25)\end{array}$ \\
\hline $\log \left(I B_{t-1}^{H}\right)$ & & $\begin{array}{l}1.11^{* *} \\
(0.41)\end{array}$ & & $\begin{array}{l}-0.06 \\
(0.09)\end{array}$ & & $\begin{array}{l}0.96 * * \\
(0.36)\end{array}$ & & $\begin{array}{c}0.70^{* * * *} \\
(0.19)\end{array}$ \\
\hline $\log \left(P_{t-1}^{H}\right)$ & $\begin{array}{l}-0.13 \\
(0.61)\end{array}$ & & $\begin{array}{l}-4.11 \\
(4.21)\end{array}$ & & $\begin{array}{c}8.57 \\
(6.94)\end{array}$ & & $\begin{array}{c}0.75 \\
(0.43)\end{array}$ & \\
\hline Adj R-squared & 0.77 & 0.99 & 0.82 & 0.98 & 0.75 & 0.99 & 0.99 & 0.99 \\
\hline \# observations & 15 & 15 & 6 & 6 & 11 & 11 & 9 & 9 \\
\hline
\end{tabular}

***: $\mathrm{p}<0.01 ;{ }^{* *}: \mathrm{p}<0.05 ;{ }^{*}: \mathrm{p}<0.10$ (two-sided tests). 
Figure 1:

Graphical Illustration of the Sample
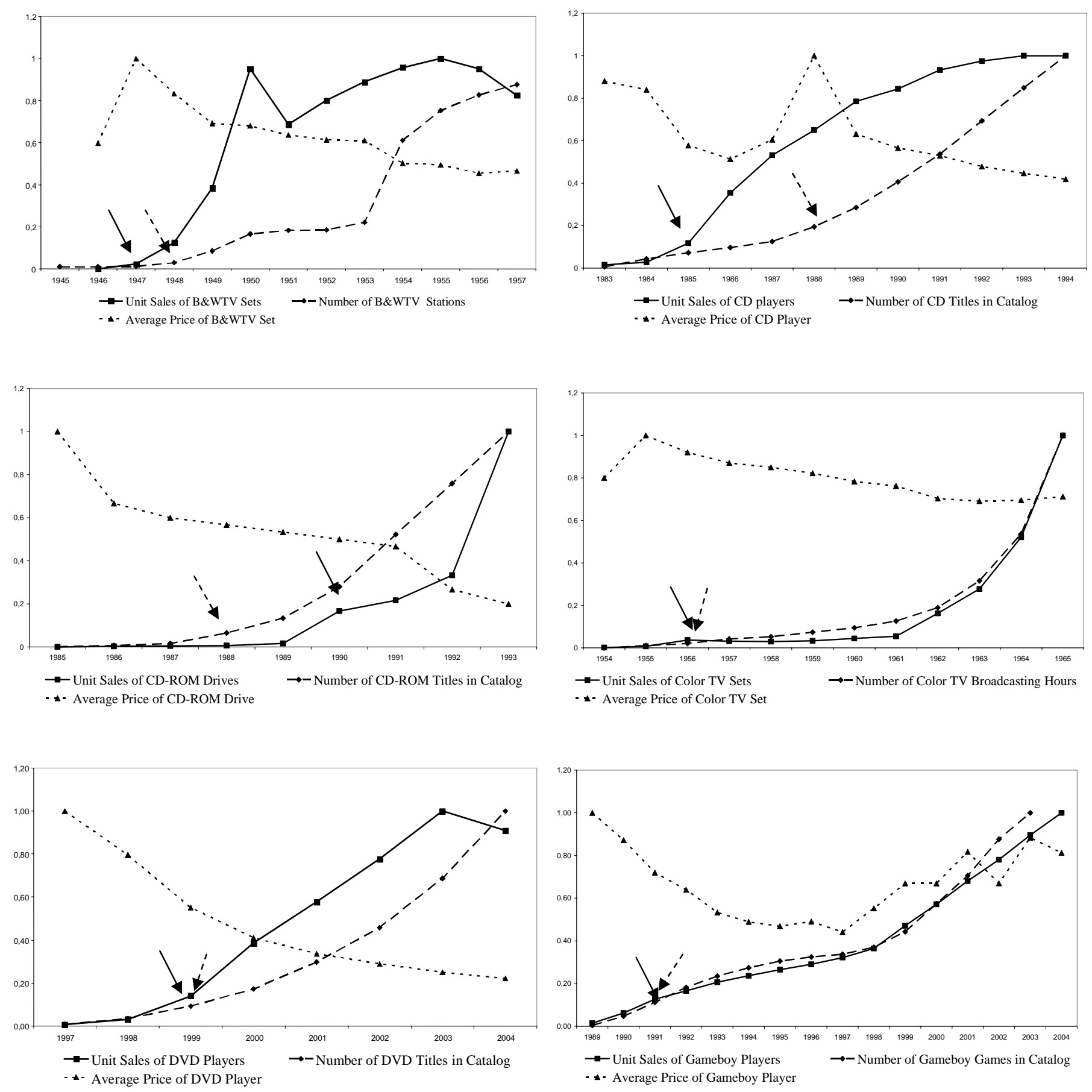

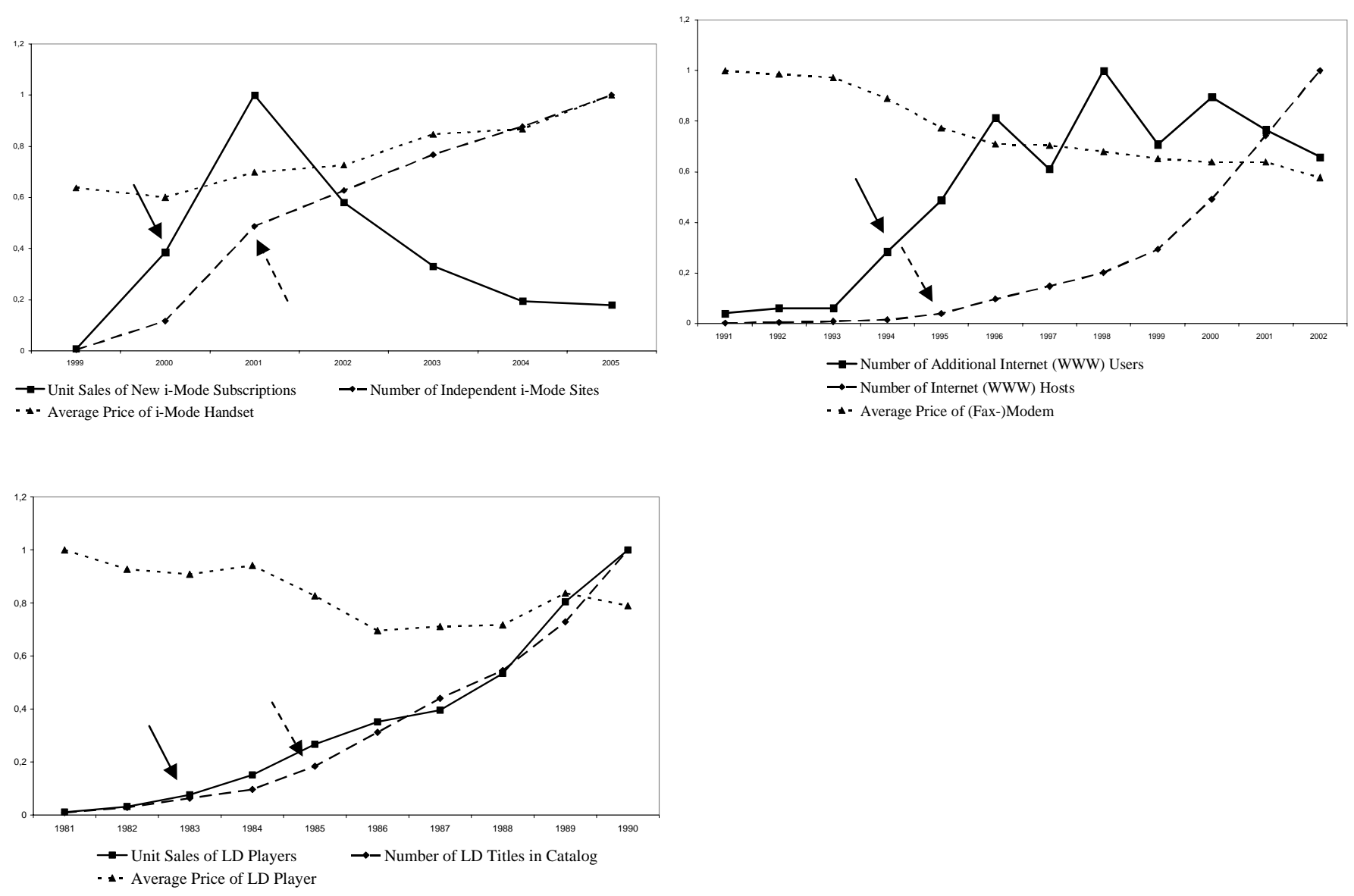

\section{Legend:}

The full lines with squares indicate hardware unit sales. Dashed lines with diamonds indicate software availability. Dotted lines with triangles indicate the hardware price evolution.

A full arrow indicates hardware sales takeoff. A dashed arrow indicates software availability takeoff. 
Figure 2:

\section{Graphical Overview of Empirical Model}

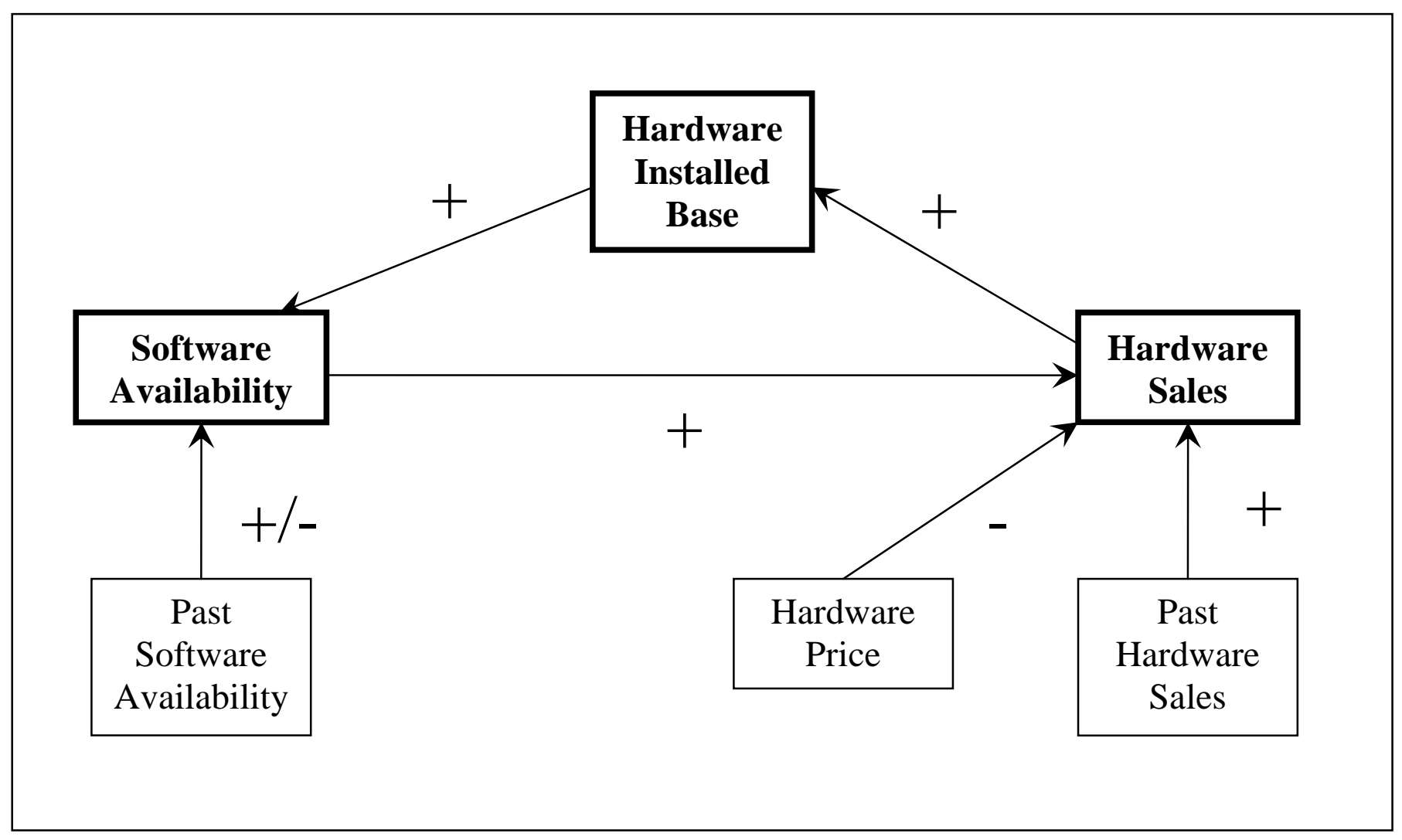


Figure 3:

Indirect Network Effects in Nine Markets

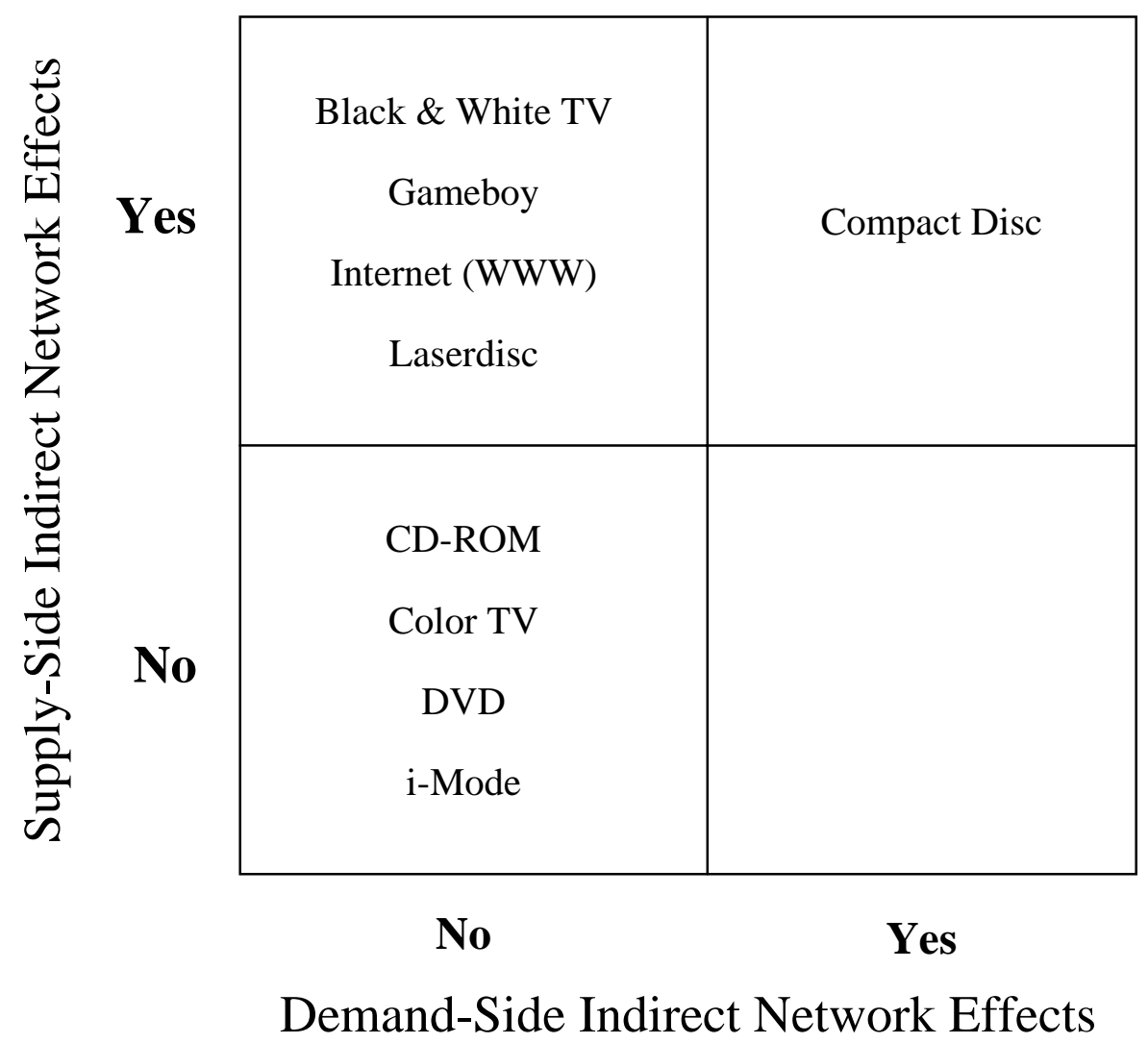




\section{References}

Agarwal, Rajshree and Barry L. Bayus (2002), “The Market Evolution and Take-off of Product Innovations,” Management Science, 48 (8), 1024-1041.

Allen, Jules (2003), “Are You Game?,” St. Petersburg Times, January 27, 2003.

Alpert, Mark (1992), “CD-ROM: The Next PC Revolution,” Fortune, New York, June 29, 1992, 6873.

Andreozzi, Luciano (2004), “A Note on Critical Masses, Network Externalities and Converters,” International Journal of Industrial Organization, 22 (5), 647- 653.

Basu, Amiya, Tridib Mazumdar and S. P. Raj (2003), "Indirect Network Externality Effects on Product Attributes,” Marketing Science, 22 (2), 209-221.

Bayus, Barry L. (1987), "Forecasting Sales of New Contingent Products: An Application to the Compact Disc Market,” Journal of Product Innovation Management, 4 (4), 243-255.

Bayus, Barry L., Wooseong Kang and Rajshree Agarwal (2006), "Creating Growth in New Markets: A Simultaneous Model of Firm Entry and Price,” Journal of Product Innovation Management, forthcoming.

Bental, Benjamin and Menahem Spiegel (1995), "Network Competition, Product Quality, and Market Coverage in the Presence of Network Externalities,” Journal of Industrial Economics, 43 (2), 197-208.

Bonardi, Jean-Philippe and Rodolphe Durand (2003), "Managing Network Effects in High-Tech Markets," Academy of Management Executive, 17 (4), 40-52.

Brynjolfsson, Erik and Chris F. Kemerer (1996), "Network Externalities in Microcomputer Software: An Econometric Analysis of the Spreadsheet Market,” Management Science, 42 (12), 1627-1647.

Bucklin, Louis P. and Sanjit Sengupta (1993), “The Co-Diffusion of Complementary Innovations: Supermarket Scanners and UPC Symbols,” Journal of Product Innovation Management, 10 (2), 148160.

Caillaud, Bernard and Bruno Jullien (2003), "Chicken \& Egg: Competition among Intermediation Service Providers,” RAND Journal of Economics, 34 (2), 309-328.

Choi, Jay Pi1 (1994), “Network Externality, Compatibility Choice, and Planned Obsolescence,” Journal of Industrial Economics, 42 (2), 167- 182.

Chou, Chien-fu and Oz Shy (1990), “Network Effects without Network Externalities,” International Journal of Industrial Organization, 8 (2), 259-270.

---- and ---- (1993), “Partial Compatibility and Supporting Services,” Economics Letters, 41 (2), 193197.

---- and ---- (1996), “Do Consumers Gain or Lose When More People Buy the Same Brand,”

European Journal of Political Economy, 12 (2), 309-330. 
Church, Jeffrey and Neil Gandal (1992a), "Network Effects, Software Provision, and Standardization,” Journal of Industrial Economics, 40 (1), 85-103.

---- and ---- (1992b), “Integration, Complementary Products, and Variety,” Journal of Economics and Management Strategy, 1 (4), 651-675.

---- and ---- (1993), “Complementary Network Externalities and Technological Adoption,” International Journal of Industrial Organization, 11 (2), 239-260.

---- and ---- (1996), “Strategic Entry Deterrence: Complementary Products as Installed Base,” European Journal of Political Economy, 12 (2), 331-354.

Clark, Bruce H. and Sangit Chatterjee (1999), “The Evolution of Dominant Market Shares: The Role of Network Effects,” Journal of Marketing Theory and Practice, 7 (2), 83-96.

Clements, Matthew T. (2004), “Direct and Indirect Network Effects: Are They Equivalent?,” International Journal of Industrial Organization, 22 (5), 633-645.

---- and Hiroshi Ohashi (2005), "Indirect Network Effects and the Product Cycle: Video Games in the U.S., 1994-2002,” Journal of Industrial Economics, 53 (4), 515-542.

Conner, Kathleen R. (1995), “Obtaining Strategic Advantage from Being Imitated: When Can Encouraging "Clones" Pay?,” Management Science, 41 (2), 209-225.

Cottrell, Tom and Ken Koput (1998), "Software Variety and Hardware Value: A Case Study of Complementary Network Externalities in the Microcomputer Software Industry,” Journal of Engineering and Technology Management, 15 (4), 309-338.

Dhebar, Anirudh (1995), “Complementarity, Compatibility, and Product Change: Breaking with the Past?,” Journal of Product Innovation Management, 12 (2), 136-152.

Dick, Jeff T. (1990), "Laserdisc Redux, Once Considered a Dead Format, Laser Videodisc may be your Library’s Next New Collection,” Library Journal, 115 (20), 36-40.

Dranove, David and Neil Gandal (2003), "The DVD-vs.-DIVX Standard War: Empirical Evidence of Network Effects and Preannouncement Effects," Journal of Economics \& Management Strategy, 12 (3), 363-386.

Ducey, Richard V. and Mark R. Fratrik (1989), "Broadcasting Industry Response to New Technologies,” Journal of Media Economics, 2 (Fall), 67-86.

Economides, Nicholas (1989), "Desirability of Compatibility in the Absence of Network Externalities,” American Economic Review, 79 (5), 1165-1181.

---- (1996), “Network Externalities, Complementarities, and Invitations to Enter,” European Journal of Political Economy, 12 (2), 211-233.

---- and Charles Himmelberg (1995), "Critical Mass and Network Size with Application to the US FAX Market,” Working Paper, Stern School of Business, New York University.

---- and Steven C. Salop (1992), “Competition and Integration Among Complements, and Network Market Structure,” Journal of Industrial Economics, 40 (1), 105-123. 
---- and Lawrence J. White (1994), “Networks and Compatibility: Implications for Antitrust,” European Economic Review, 38 (3-4), 651-662.

Elliott, G., T.J. Rothenberg and J.H. Stock (1996), "Efficient Tests for an Autoregressive Unit Root," Econometrica, 64 (4), 813-836.

Esser, Patrick and Luc Leruth (1988), "Marketing Compatible, yet Differentiated, Products: In Search of Competitive Equilibria when Network Externalities are at Work," International Journal of Research in Marketing, 5 (4), 251-270.

Farrell, Joseph and Garth Saloner (1985), “Standardization, Compatibility, and Innovation,” RAND Journal of Economics, 16 (1), 70-83.

---- and ---- (1986), “Installed Base and Compatibility: Innovation, Product Preannouncements, and Predation,” American Economic Review, 76 (5), 940-955.

----, Carl Shapiro, Richard R. Nelson and Roger G. Noll (1992), "Standard Setting in High-Definition Television,” Brookings Papers: Microeconomics. Brookings Institution, Washington D.C.

Franses, Philip Hans (1998), Time Series Models for Business and Economic Forecasting, Cambridge, UK: Cambridge University Press.

---- (2005), “On the Use of Econometric Models for Policy Simulation in Marketing,” Journal of Marketing Research, 42 (1), 4-14.

Frels, Judy K., Tasadduq Shervani and Rajendra K. Srivastava (2003), “The Integrated Networks Model: Explaining Resource Allocations in Network Markets,” Journal of Marketing, 67 (1), 29-45.

Gandal, Neil (1994), "Hedonic Price Indexes for Spreadsheets and an Empirical Test for Network Externalities,” RAND Journal of Economics, 25 (1), 160-170.

---- (1995), "Competing Compatibility Standards and Network Externalities in the PC Software Market,” Review of Economics and Statistics, 77 (4), 599-608.

---- (2002), “Compatibility, Standardization, and Network Effects,” Oxford Review of Economic Policy, 18 (1), 80-91.

----, Shane Greenstein and David Salant (1999), “Adoptions and Orphans in the Early

Microcomputer Market,” Journal of Industrial Economics, 47 (1), 87-105.

----, Michael Kende and Rafael Rob (2000), “The Dynamics of Technological Adoption in Hardware/Software Systems: The Case of Compact Disc Players,” Rand Journal of Economics, 31 (1), 43-61.

Garud, Raghu and Arun Kumaraswamy (1993), "Changing Competitive Dynamics in Network Industries: An Exploration of Sun Microsystems' Open Systems Strategy,” Strategic Management Journal, 14 (5), 351-369.

Golder, Peter N. and Gerard J. Tellis (1997), "Will It Ever Fly? Modeling the Takeoff of Really New Consumer Durables,” Marketing Science, 16 (3), 256-270.

---- and ---- (1998), "Beyond Diffusion: An Affordability Model of the Growth of New Consumer Durables,” Journal of Forecasting, 17 (3-4), 259-280. 
---- and ---- (2004), “Growing, Growing, Gone: Cascades, Diffusion, and Turning Points in the Product Life Cycle,” Marketing Science, 23 (2), 207-218.

Granger, Clive W.J. (1969), "Investigating Causal Relations by Econometric Methods and CrossSpectral Methods,” Econometrica, 34, 424-438.

Granovetter, Mark (1978), “Threshold Models of Collective Behavior,” American Journal of Sociology, 83 (6), 1420-1443.

Gupta, Sachin, Dipak C. Jain and Mohanbir S. Sawhney (1999), "Modeling the Evolution of Markets with Indirect Network Externalities: An Application to Digital Television,” Marketing Science, 18 (3), 396-416.

Hahn, Jong-Hee (2003), "Nonlinear Pricing of Telecommunications with call and Network Externalities,” International Journal of Industrial Organization, 21 (7), 949-967.

Hartman, Raymond S. and David J. Teece (1990), "Product Emulation Strategies in the Presence of Reputation Effects and Network Externalities: Some Evidence from the Minicomputer Industry,” Economics of Innovation and New Technology, 1 (1), 157-182.

Hill, Charles W.L. (1997), "Establishing a Standard: Competitive Strategy and Technological Standards in Winner-Take-All Industries,” Academy of Management Executive, 11 (2), 7-25.

Katz, Michael L. and Carl Shapiro (1985), “Network Externalities, Competition, and Compatibility,” American Economic Review, 75 (3), 424-440.

---- and ---- (1986a), "Product Compatibility Choice in a Market with Technological Progress," Oxford Economic Papers, 38 (3), 146-165.

---- and ---- (1986b), “Technology Adoption in the Presence of Network Externalities,” Journal of Political Economy, 94 (4), 822-841.

---- and ---- (1992), “Product Introduction with Network Externalities,” Journal of Industrial Economics, 40 (1), 55-83.

---- and ---- (1994), “Systems Competition and Network Effects,” Journal of Economic Perspectives, 8 (2), 93-115.

Koski, Heli and Tobias Kretschmer (2004), "Survey on Competing in Network Industries: Firm Strategies, Market Outcomes, and Policy Implications,” Journal of Industry, Competition and Trade, 4 (1), 5-31.

Kotabe, Masaaki, Arvind Sahay and Preet S. Aulakh (1996), “Emerging Role of Technology Licensing in the Development of Global Product Strategy: Conceptual Framework and Research Propositions,” Journal of Marketing, 60 (1), 73-88.

Kristiansen, Eirik Gaard (1996), “R\&D in Markets with Network Externalities,” International Journal of Industrial Organization, 14 (6), 769-784.

---- (1998), “R\&D in the Presence of Network Externalities: Timing and Compatibility,” RAND Journal of Economics, 29 (3), 531-547. 
Lee, Yikuan and Gina Colarelli O’Connor (2003), “New Product Launch Strategy for Network Effects Products,” Journal of the Academy of Marketing Science, 31 (3), 241-255.

LeNagard-Assayag, Emmanuelle and Delphine Manceau (2001), "Modeling the Impact of Product Preannouncements in the Context of Indirect Network Externalities," International Journal of Research in Marketing, 18 (3), 203-219.

Loch, Christoph H. and Bernardo A. Huberman (1999), “A Punctuated-Equilibrium Model of Technology Diffusion,” Management Science, 45 (2), 160-177.

Macy, Michael W. (1991), “Chains of Cooperation: Threshold Effects in Collective Action,” American Sociological Review, 56 (6), 730-747.

Majumdar, Sumit K. and S. Venkataraman (1998), "Network Effects and the Adoption of New Technology: Evidence from the US Telecommunications Industry,” Strategic Management Journal, 19 (11), 1045-1062.

Matutes, Carmen and Pierre Regibeau (1988), “"Mix and Match": Product Compatibility without Network Externalities,” RAND Journal of Economics, 19 (2), 221-234.

---- and ---- (1992), “Compatibility and Bundling of Complementary Goods in a Duopoly,” Journal of Industrial Economics, 40 (1), 37-54.

McClure, Steve (1992), “Laserdisc Japan: A Massive Hit,” Billboard, 104 (6), L8-L20.

---- (1993a), “Laserdisc Rentals Coming to Japan,” Billboard 105 (29), 8.

---- (1993b), “Recession Dampens Japan's LD Market; Karaoke Explosion Helps Soften Blow,” Billboard, February 27, 1993.

McGowan, Chris (1994), “Overcoming '93s Bad Press and Slow Start, the Market Finished Solid and is Well Set Up for ’94,” Billboard, 106 (9), 63-65.

Midgette, Anne (1997), “Video: DVD’s Debut,” Wall Street Journal, April 21, A.20.

Nair, Harikesh, Pradeep Chintagunta and Jean-Pierre Dubé (2004), “Empirical Analysis of Indirect Network Effects in the Market for Personal Digital Assistants," Quantitative Marketing and Economics, 2 (1), 23-58.

Ohashi, Hiroshi (2003), “The Role of Network Effects in the US VCR Market, 1978-1986,” Journal of Economics \& Management Strategy, 12 (4), 447-494.

Park, Sangin (2004), “Quantitative Analysis of Network Externalities in Competing Technologies: The VCR Case,” Review of Economics and Statistics, 86 (4), 937-945.

Pescovitz, David (1997), “DVD Certainly Dazzles, but High Cost is Stalling its Acceptance,” The Los Angeles Times, July 21.

Peterson, Robert A. and Vijay Mahajan (1978), “Multi-Product Growth Models,” Research in Marketing, 1, 201-231.

Pope, Kyle (1999), “The Small Screen. Too-high Expectations: Top-quality Digital TV Was Supposed to be Thriving by Now; What Happened?,” Wall Street Journal, March 22, R8. 
Postrel, Steven R. (1990), "Competing Networks and Proprietary Standards: The Case of Quadraphonic Sound,” Journal of Industrial Economics, 39 (2), 169-185.

Putsis Jr., William P., Sridhar Balasubramanian, Edward H. Kaplan and Subrata K. Sen (1997), “Mixing Behavior in Cross-Country Diffusion,” Marketing Science, 16 (4), 354-369.

Ratliff, John M. (2002), “NTT DoCoMo and Its i-Mode Success: Origins and Implications,” California Management Review, 44 (3), 55-71.

Rogers, Everett M. (1995), Diffusion of Innovations, $4^{\text {th }}$ ed. New York, NJ: The Free Press.

Rohlfs, Jeffrey (2001), Bandwagon Effects in High-Technology Industries. Cambridge, MA: The MIT Press.

Rowe, Garrett (1999), “Where's Your White Stick, Ref?,” The Irish Times, May 3, 1999.

Rysman, Marc (2004), “Competition between Networks: A Study of the Market for Yellow Pages,” Review of Economic Studies, 71 (2), 483-512.

Saloner, Garth and Andrea Shepard (1995), “Adoption of Technologies with Network Effects: An Empirical Examination of the Adoption of Automated Teller Machines," RAND Journal of Economics, 26 (3), 479-501.

Schelling, Thomas (1978), Micromotives and Macrobehavior. New York, NJ: Norton.

Schilling, Melissa A. (1999), "Winning the Standards Race: Building Installed Base and the Availability of Complementary Goods,” European Management Journal, 17 (3), 265-274.

---- (2002), “Technology Success and Failure in Winner-Take-All Markets: The Impact of Learning Orientation, Timing and Network Externalities,” Academy of Management Journal, 45 (2), 387-398.

Sengupta, Sanjit (1998), “Some Approaches to Complementary Product Strategy,” Journal of Product Innovation Management, 15 (4), 352-67.

Shankar, Venkatesh and Barry L. Bayus (2003), "Network Effects and Competition: An Empirical Analysis of the Video Game Industry,” Strategic Management Journal, 24 (4), 375-384.

Shapiro, Carl and Hal R. Varian (1998), Information Rules: A Strategic Guide to the Network Economy. Boston, MA: Harvard Business School Press.

Sheremata, Willow A. (2004), “Competing Through Innovation in Network Markets: Strategies for Challengers,” Academy of Management Review, 29 (3), 359-377.

Shurmer, Mark (1993), “An Investigation into Sources of Network Externalities in the Packaged PC Software Market,” Information Economics and Policy, 5 (1), 231-251.

Shy, Oz (1996), “Technology Revolutions in the Presence of Network Externalities,” International Journal of Industrial Organization, 14 (6), 785-800.

---- (2001), The Economics of Network Industries, New York, NY: Cambridge University Press.

Srinivasan, Raji, Gary L. Lilien and Arvind Rangaswamy (2004), "First In, First Out? The Effects of Network Externalities on Pioneer Survival,” Journal of Marketing, 68 (1), 41-58. 
Sterling, Christopher H. and John Michael Kittross (2002), Stay Tuned: A History of American Broadcasting, $3^{\text {rd }}$ edition. Mahwah, NJ: Lawrence Erlbaum Associates Publishers.

Stremersch, Stefan and Gerard J. Tellis (2004), "Understanding and Managing International Growth of New Products," International Journal of Research in Marketing, 21 (4), 421-438.

Sun, Boahong, Jinhong Xie and H. Henry Cao (2004), "Product Strategy for Innovators in Markets with Network Effects,” Marketing Science, 23 (2), 243-254.

Tam, Pui-Wing (2000), “Army of Programmers Helps Palm Keep Its Edge - Loyal Independent Designers Decline to Adapt Software for Rival Microsoft System,” Wall Street Journal, June 1, B1.

Tellis, Gerard J., Stefan Stremersch and Eden Yin (2003), “The International Takeoff of New Products: The Role of Economics, Culture, and Country Innovativeness,” Marketing Science, 22 (2), 188-208.

Thum, Marcel (1994), "Network Externalities, Technological Progress, and the Competition of Market Contracts,” International Journal of Industrial Organization, 12 (2), 269-289.

Tucker, Catherine (2006), "Interactive, Option-Value and Domino Network Effects in Technology Adoption,” working paper.

Valente, Thomas W. (1995), Network Models of the Diffusion of Innovations. Cresskill, NJ: Hampton Press.

Van den Bulte, Christophe (2000), "New Product Diffusion Acceleration: Measurement and Analysis,” Marketing Science, 19 (4), 366-80.

---- and Stefan Stremersch (2004), "Social Contagion and Income Heterogeneity in New Product Diffusion: A Meta-Analytic Test,” Marketing Science, 23 (4), 530-544.

Viswanathan, Siva (2005), "Competing Across Technology-Differentiated Channels: The Impact of Network Externalities and Switching Costs,” Management Science, 51 (3), 483-496.

Wade, James (1995), "Dynamics of Organizational Communities and Technological Bandwagons: An Empirical Investigation of Community Evolution in the Microprocessor Market,” Strategic Management Journal, 16 (6), 111-133.

Williams, Dmitri (2002), "Structure and Competition in the U.S. Home Video Game Industry," International Journal on Media Management, 4 (1), 41-54.

Witt, Ulrich (1997) ““'Lock-in” vs. “Critical Masses” - Industrial Change under Network Externalities,” International Journal of Industrial Organization, 15 (6), 753-773.

Xie, Jinhong and Marvin Sirbu (1995), "Price Competition and Compatibility in the Presence of Positive Demand Externalities,” Management Science, 41 (5), 909-926.

Yoder, Stephen Kreider (1990), “Sony to Market Digital Tape Decks in U.S.,” Wall Street Journal, June 5, B4.

Ziegler, Bart (1994), "IBM to Spend \$100 Million on Ad Blitz to Launch Two PC Lines, New Image,” Wall Street Journal, September 19, B9. 
Appendix: Data

\begin{tabular}{|c|c|c|c|c|c|}
\hline Network Market & Series & Operationalization & Time Period & Country & Data source \\
\hline \multirow[b]{2}{*}{ B\&W Television } & Hardware Sales & Retail Unit Sales of B\&W Television Sets to Consumers & 1946-1957 & U.S. & The Broadcasting Yearbook \\
\hline & Hardware Installed Base & $\begin{array}{c}\text { Cumulative Retail Unit Sales of B\&W Television Sets to } \\
\text { Consumers }\end{array}$ & 1946-1957 & U.S. & Own derivation \\
\hline \multirow{4}{*}{ Compact Disc } & Software Availability & Number of TV Stations on Air & $1945-1957$ & U.S. & The Broadcasting Yearbook and FCC \\
\hline & Hardware Sales & Retail Unit Sales of Compact Disc Players to Consumers & 1983-1994 & U.K. & Philips Consumer Electronics \\
\hline & Hardware Installed Base & $\begin{array}{l}\text { Cumulative Retail Unit Sales of Compact Disc Players to } \\
\text { Consumers }\end{array}$ & 1983-1994 & U.K. & Own derivation \\
\hline & Software Availability & Number of Compact Disc Titles in Catalog & 1983-1994 & U.K. & The British Phonographic Industry Ltd \\
\hline \multirow{2}{*}{ CD-ROM } & Hardware Sales & Retail Unit Sales of CD-ROM Drives to Consumers & 1985-1993 & U.S. & Peter Golder \\
\hline & Hardware Installed Base & Cumulative Retail Unit Sales of CD-ROM Drives to Consumers & $1985-1993$ & U.S. & Own derivation \\
\hline \multirow{5}{*}{ Color Television } & Hardware Price & Average Price of CD-ROM Drive & 1985-1993 & U.S. & Peter Golder \\
\hline & Software Availability & Number of CD-ROM Titles in Catalog & 1985-1993 & U.S. & CD-ROM Directory \\
\hline & Hardware Sales & Retail Unit Sales of Color Television Sets to Consumers & 1954-1965 & U.S. & Consumer Electronics Association \\
\hline & Hardware Installed Base & $\begin{array}{c}\text { Cumulative Retail Unit Sales of Color Television Sets to } \\
\text { Consumers }\end{array}$ & 1954-1965 & U.S. & Own derivation \\
\hline & Software Availability & Number of Hours Broadcasted in Color (all stations) & 1954-1965 & U.S. & Ducey and Fratrik (1989) \\
\hline \multirow{2}{*}{ DVD } & Hardware Sales & Number of DVD Players Shipped to Dealers & $1997-2004$ & U.S. & Consumer Electronics Association \\
\hline & Hardware Installed Base & Cumulative Number of DVD Players Shipped to Dealers & $1997-2004$ & U.S. & Own derivation \\
\hline \multirow{6}{*}{ Gameboy } & Hardware Price & Average Price of DVD Player & $1997-2004$ & U.S. & eBrain Market Research \\
\hline & Software Availability & Number of DVD Titles in Catalog & 1997-2004 & U.S. & http://www.hometheaterinfo.com/ \\
\hline & Hardware Sales & Retail Unit Sales of Gameboy to Consumers & 1989-2004 & U.S. & NPD \\
\hline & Hardware Installed Base & Cumulative Retail Unit Sales of Gameboy to Consumers & 1989-2004 & U.S. & Own derivation \\
\hline & Hardware Price & Average Price of Gameboy Player & 1989-2002 & U.S. & NPD and Nintendo \\
\hline & Software Availability & Number of Gameboy Games Available to Consumers & $1989-2003$ & U.S. & Nintendo \\
\hline \multirow{2}{*}{ i-Mode ${ }^{8}$} & Hardware Sales & Number of New i-Mode Subscribers & 1999-2005 & Japan & Own derivation \\
\hline & Hardware Installed Base & Total Number of i-Mode Subscribers & 1999-2005 & Japan & NTT DoCoMo \\
\hline
\end{tabular}

${ }^{8}$ i-Mode is a high-speed mobile Internet service (2.5G) introduced first in Japan by NTT DoCoMo. 


\begin{tabular}{|c|c|c|c|c|c|}
\hline & Hardware Price & Average Price of Advertised i-Mode Handset & 1999-2005 & Japan & Ascii24.com \\
\hline & Software Availability & Number of Independent i-Mode Sites & 1999-2005 & Japan & OH!NEW i-search (www.ohnew.co.jp) \\
\hline \multirow{3}{*}{ Internet (WWW) } & Hardware Sales & Number of Additional Internet (WWW) Users & 1991-2002 & U.S. & Own derivation \\
\hline & Hardware Installed Base & Total Number of Internet (WWW) Users & 1991-2002 & U.S. & Internet Software Consortium \\
\hline & Software Availability & Number of Internet (WWW) Hosts & 1991-2003 & U.S. & International Telecommunication Union \\
\hline \multirow{4}{*}{ Laserdisc } & Hardware Sales & Number of Laserdisc Players Shipped to Dealers & 1981-1990 & Japan & Philips Consumer Electronics \\
\hline & Hardware Installed Base & Cumulative Number of Laserdisc Players Shipped to Dealers & 1981-1990 & Japan & Own derivation \\
\hline & Hardware Price & $\begin{array}{c}\text { Average Manufacturer Suggested Retail Price of in year } t \text { released } \\
\text { Laserdisc Player }\end{array}$ & 1981-1990 & Japan & Variety of sources \\
\hline & Software Availability & Number of Laserdisc Titles in Catalog & 1981-1990 & Japan & Philips Consumer Electronics \\
\hline
\end{tabular}

Table A1: Detailed overview of the data 


\section{Publications in the Report Series Research ${ }^{*}$ in Management}

\section{ERIM Research Program: "Marketing"}

2007

Marketing Communication Drivers of Adoption Timing of a New E-Service Among Existing Customers Remco Prins and Peter C. Verhoef ERS-2007-018-MKT

Indirect Network Effects in New Product Growth

Stefan Stremersch, Gerard J. Tellis, Philip Hans Franses and Jeroen L.G. Binken ERS-2007-019-MKT

A complete overview of the ERIM Report Series Research in Management: https://ep.eur.nl/handle/1765/1

ERIM Research Programs:

LIS Business Processes, Logistics and Information Systems

ORG Organizing for Performance

MKT Marketing

F\&A Finance and Accounting

STR Strategy and Entrepreneurship 